\title{
İslamî Psikolojinin İmkânı, Gerekliliği ve Nasıllığı
}

\author{
Üsame Balıkçı \\ Ar. Gör., Sakarya Üniversitesi (ROR ID: 04ttnw109) \\ İlahiyat Fakültesi, Din Psikolojisi Anabilim Dalı \\ Research Ass., Sakarya University, Faculty of Theology \\ Department of Psychology of Religion \\ Sakarya/Turkey \\ usamebalikci@sakarya.edu.tr \\ ORCID: 0000-0002-6095-4151
}

\begin{abstract}
Undoubtedly, every scientist researches and develops his/her theories in accordance with the spirit of his/her age (Zeitgeist) within the framework of the possibilities and limits of the culture and civilization he/she lives in. The scientific basis and character of the psychology that has been developed in modern Western thought, is also subject to these possibilities and limits. Psychology, which emerged as a separate discipline from philosophy in the 19th century with its unique concepts and theories, is based on the Judeo-Christian tradition and positivist understanding of science in the context of its possibilities and limits. It is controversial to what extent psychology is valid for individuals with different worldviews due to the paradigm and foundations that have been effective in its historical development. This study aimed to find an answer to 'how/to what extend' the Islamic psychology tradition should be formed by discussing the adequacy of modern psychology to identify individuals with an Islamic worldview as the basic method to be used in recognizing the human spirit. In the study, which consisted of two stages, is evaluated firstly, the possibility of adapting modern psychology to the Islamic worldview and secondly the possibility of establishing a psychology-based only on Islamic sources.

Considering the course of historical development, it can be observed that modern psychology has witnessed some changes with the effect of the loss of validity of the meta-ideas of modernity and the pluralism of post-modernism that supports different ways of knowing. In line with these developments, it can be said that psychology has moved away from a monotype, but universal character and has become a scientific discipline that takes into account intercultural differences and does not deny the transcendent dimension of human beings. The evolving process from Freud to Frankl or from behaviorism to cognitive-behavioral and transper-
\end{abstract}

İtihal Taraması/Plagiarism Detection: Bu makale intihal taramasından geçirildi/This paper was checked for plagiarism Etik Beyan/Ethical Statement: Bu çalışmanın hazırlanma sürecinde bilimsel ve etik ilkelere uyulduğu ve yararlanılan tüm çalışmaların kaynakçada belirtildiği beyan olunur/It is declared that scientific and ethical principles have been followed while carrying out and writing this study and that all the sources used have been properly cited (Üsame Balıkçı).

Geliş/Received: 26 Haziran/June 2021 | Kabul/Accepted: 25 Ağustos/August 2021 | Yayın/Published: 20 Eylül/September 2021 Atıf/Cite as: Üsame Balıkçı, "İslamî Psikolojinin İmkânı, Gerekliliği ve Nasıllığı = Possibility, Necessity and Nature of Islamic Psychology”, Eskiyeni 44 (Eylül/September 2021), 409-431. https://doi.org/10.37697/eskiyeni.957836 CC BY-NC 4.0 | This paper is licensed under a Creative Commons Attribution-NonCommercial License 
sonal psychology theories reveals that psychology has progressed from methodical atheism to an area open to beliefs. Although the relationship with the transcendental field and the appreciation of the knowledge from that field paves the way for groundings in accordance with the Islamic worldview, its adherence to the scientific paradigm that accepts the human mind as a single-center and authority poses an obstacle to the Islamization of psychology as it is. On the ground that the concepts and principles of the scientific method established according to the Islamic belief must be taken either directly from God through revelation or from the interpretation of the signs hidden in the revelation. The foremost feature of the Islamic science characteristic is that it is shaped according to the principle of revelation and tawhid. However, when the Qur'an, hadith, and the interpretations of Muslim scholars that emerged in the historical process are examined, it is seen that the accumulation of psychology shows more metaphysical, ethical, and ontological characteristics. Based on this accumulation, although it is possible to identify the nature, limits, and spiritual weaknesses of human beings and to offer a prescription for moral recovery, it is understood that this accumulation does not have the effect and functionality to replace contemporary understanding of science. As a result, a method based on enriching the metaphysical, ontological, and ethical theoretical framework in Islamic sources with modern psychology techniques is proposed for psychology that appeals to the present, universal and human reality. While understanding God, the universe, and human beings nourish from Islamic sources, the concepts and techniques used should be taken from modern psychology.

\section{Keywords}

Psychology of Religion, Islamic Psychology, Modern Psychology, God-Human, Religion-Science

\section{İslamî Psikolojinin İmkânı, Gerekliliği ve Nasılllğı}

\section{Öz}

Şüphesiz her bilim insanı içinde yaşadığı kültür ve medeniyetin imkân ve sınırları çerçevesinde, çağının ruhuna (Zeitgeist) uygun olarak araştırır ve teorilerini geliştirir. Modern Batı düşüncesi içerisinde gelişen psikoloji biliminin bilimsel temel ve karakteri de bu imkân ve sınırlara tabidir. Kendine özgü kavram ve kuramlarıla 19.yüzyılda felsefeden ayrı bir disiplin olarak ortaya çıkan psikoloji bilimi, sahip olduğu imkân ve sınırlar bağlamında HristiyanYahudi dünya görüşü ve pozitivist bilim anlayışı temeline oturmaktadır. Tarihsel gelişiminde etkin olan paradigma ve dayandığı temeller sebebiyle psikolojinin farklı dünya görüşüne sahip bireyler için ne derece geçerli olduğu tartışmalıdır. Bu çalışmada da insan ruhunu tanımada kullanılacak temel metod olarak modern psikolojinin İslamî dünya görüşüne sahip bireyleri ifade etme yeterliliği tartışılarak İslamî psikoloji geleneğinin oluşturulmasının 'nasılı' sorusuna cevap aramak hedeflendi. İki aşamadan oluşan araştırmada öncelikle modern psikolojinin İslam dünya görüşüne uyarlanması imkânı, daha sonra sadece İslamî kaynaklara dayanan bir psikoloji geleneğinin oluşturulması imkânı değerlendirildi.

Tarihsel gelişim seyri dikkate alındığında modern psikolojinin, modernitenin meta idealarının geçerliliğini yitirmesi ve post modernizmin farklı bilme biçimlerini destekleyen çoğulculuğunun etkisiyle bazı değişikliklere tanıklık ettiği gözlemlenebilir. Bu gelişmeler doğrultusunda psikolojinin, tek tip ama evrensel bir karakterden uzaklaşarak kültürlerarası farklılığı dikkate alan ve insanının aşkın boyutunu inkâr etmeyen bir bilim disiplin haline geldiği söylenebilir. Freud'dan Frankl'a yahut davranışçlıktan bilişsel davranışçı ve transpersonal psikoloji kuramlarına doğru evrilen süreç, psikolojinin metodik ateizmden sıyrılıp inançlara açı bir alana doğru gelişme kaydettiğini ortaya koyar. Aşkın alanla ilişki ve o alandan gelen bilginin değer 
kazanması İslam dünya görüşüne uygun temellendirmelerin önünü açsa da insan aklını tek merkez ve otorite kabul eden bilimsel paradigmaya bağlılı̆̆ını sürdürmesi psikolojinin olduğu haliyle İslamîleşmesi önünde bir engel teşkil eder. Zira İslam inancına göre oluşturulacak bilimsel metodun kavram ve ilkeleri ya doğrudan vahiy yoluyla Tanrı'dan ya da vahiyde gizlenen işaretlerin yorumundan alınmalıdır. İslam bilim karakteristiğinin en önemli özelliği vahiy ve tevhit ilkesine göre şekillenmiş olmasıdır. Ancak Kur'an, hadis ve tarihsel süreçte ortaya çıkan Müslüman düşünürlerin yorumlarını incelediğimizde ruh bilimine ilişkin birikimlerin fazla metafizik, etik ve ontolojik özellikler gösterdiğini görüyoruz. Bu birikime dayanarak insanın doğasını, sınırlarını, ruhsal anlamda zaaflarını tespit etmek ve ahlâkî açıdan iyileşmesi yolunda bir reçete sunmak mümkün olsa da günümüz bilim anlayışının yerini dolduracak etki ve işlevselliğe sahip olmadığı anlaşılmaktadır. Sonuç olarak günümüze, evrensele ve insanın gerçekliğine hitap eden psikoloji için İslamî kaynaklardaki metafizik, ontolojik ve etik kuramsal çerçevenin modern psikoloji teknikleriyle zenginleştirilmesine dayanan bir yöntem önerilmektedir. Allah, âlem ve insan anlayışı İslamî kaynaklardan beslenirken kullanılan kavram ve teknikler modern psikolojiden alınmalıdır.

\section{Anahtar Kelimeler}

Din Psikolojisi, İslamî Psikoloji, Modern Psikoloji, Tanrı-İnsan, Din-Bilim

\section{Giriş}

Akademik bir disiplin olarak psikolojinin ortaya çıkışı 19. yüzyılın ikinci yarısına tesadüf etmektedir. Fakat yapısı gereği yaşadığı evreni ve kendi özünü merak eden insanın psikolojinin konusu olan insan duygu ve davranışlarını incelemesi, insanlığın ilk tarihlerine kadar götürülebilir. Ruh, ruhun yapısı, ruhun bedenle ilişkisi, uyku, rüya, duygu durumu ve bozuklukları, duygu davranış ilişkisi ve ölüm gibi konular her dönemde insanın ciddi anlamda merak ettiği ve araştırdığı konulardan biri olmuştur. Bununla birlikte entelektüel bir etkinlik olarak ilk sistemli araştırma ve açıklamaların antik Yunan'da yapıldığı kabul edilir. ${ }^{1}$ Kendine has konu, yöntem ve teknikleriyle ayrı bir disiplin olarak ortaya çıkışı ise 19. yüzyılın ikinci yarısına tekabül etmiştir. Gerek antik Yunan'ı temel alması ve gerek aydınlanmanın tesirinde gelişen 19. yüzyılın bilimsel paradigmalarına göre şekillenmesi psikolojiyi, HristiyanYahudi dünya görüşü ve pozitivist bilim anlayışı temeline oturtmaktadır. ${ }^{2}$ Temellendiği paradigmalar açısından söz konusu psikolojinin Müslüman dünya görüşüne sahip bireyleri ifade etme yeterliliği ve işlevselliği tartışmalıdır. Bu bağlamda psikolojinin İslamîleştirilmesi mümkün mü sorusu gündeme gelmektedir. Tabii, psikoloji özelindeki bu tartışma paradigmatik ilkelere dayandığı için bilginin İslamîleştirilmesi mümkün mü sorusuyla da yakından ilişkilidir.

Genel olarak bilginin İslamîleştirilmesi ile kastedilen, modern bilim anlayışının ontik ve epistemik sınırlarına sıkışmış İslam dünya görüşüne ait bilme yöntemini

1 bk. Duane P Schultz - Sydney Ellen Schultz, Modern Psikoloji Tarihi, çev. Yasemin Aslay (ìstanbul: Kaknüs Yayınları, 2020), 25; Neda Armaner, Din Psikolojisine Giriş (Ankara: Ayyıldız Matbaası, 1980), 15-16; Kemal Sayar - Mehmet Dinç, Psikolojiye Giriş (İstanbul: Değerler Eğitim Merkezi Yayınları, 2014), 10-12; Feriha B. Baymur, Genel Psikoloji (İstanbul: İnkılâp Yayınları, 2020), 311-312.

2 Hamdi Korkman, "Pozitif Bir Bilim Olarak Psikoloji", Afyon Kocatepe Üniversitesi Sosyal Bilimler Dergisi 21/1 (Mart 2019), 345-357. 
açı̆̆a çıkarmaktır. Fârûkî’nin (öl. 1986) deyimiyle insan, tabiat ve dine ait tüm bilgilerin tevhit temeline göre yeniden düzenlenmesidir. ${ }^{3}$ Bunun için önce modern bilim disiplinleri ile İslamî bilgi birikimini iyice öğrenmek, sonra aralarındaki muhtemel sentez noktalarını aramak gerekir. Nâkıb el-Attâs'ın bilginin İslamîleştirilmesini (Islamization of knowledge) kavramsal düzeyde ilk kez 1960'larda zikretmesinden sonra İsmail R. Fârûkî, Mevdûdî (öl. 1979), Ebû Süleyman, el-Alvânî (öl. 2016) gibi birçok isim metodolojik bir arayışa girmiştir.

Çalışmamızda asıl ilgilendiğimiz konu olan Psikoloji sahasında bu vurgu 1975 yılında Müslüman Sosyal Bilimciler Derneği (AMSS)'nin gerçekleştirdiği konferansta Mâlik Bedri'nin (öl. 2021) yaptı̆̆ı 'Müslüman Psikologlar Kertenkele Deliğinde' isimli tebliğde ilk yankısını buldu. Bu tebliğden sonra neredeyse yarım asırlık bir süre içerisinde İslam ile psikoloji arasındaki bağı tartışan onlarca yerli ve yabancı bilimsel kitap ve makale kaleme alındı. ${ }^{4}$ Hökelekli'nin İslam Psikolojisi Yazıları ${ }^{5}$, Habil Şentürk'ün İbâdet Psikolojisi ${ }^{6}$ gibi kitapları, Ayten'in Arap Ülkelerinde İslami Psikoloji ve Din Psikolojisi Çalışmaları ${ }^{7}$ Ağılkaya'nın Müslüman Psikologlar Kertenkele Deliğinden Çıktı Mı? Düzgüner'in Dini Psikoloji ve İslam Psikolojisi Bağlamında Din Psikolojisini Yeniden Düşünmek ${ }^{9}$ adlı makaleleri ülkemizde yapılan başlıca çalışmalardır. Söz konusu eserlerde daha çok yeni bir psikoloji anlayışının kabullenilmesi ve İslam filozoflarının insan anlayışı gibi konular üzerinde durulmuştur. Yakın dönemde yayımlanan Uysal'ın Gelenek ile Gelecek Arasında İslamî Psikoloji ${ }^{10}$ adlı eseri ise İslamî psikolojiyi ortaya çıkartan şartları ve nasıl tanımlanması gerektiğini ele alan dikkat çekici bir eserdir. Bunların dışında alan yazına katkı sağlamak amacıyla kaleme alınan Koç'un İslami Bir

3 bk. Veysel K. Altun, “İslam Düşüncesini Yeniden İnşa Çabası: Bilginin İslamileştirilmesi”, Birey ve Toplum Sosyal Bilimler Dergisi 4/2 (Temmuz 2015), 163-192; Mohammad Mümtaz Ali, “İslam Düşüncesi ve Medeniyetinin Yeniden Yapılanması: Bilginin İslamileștirilmesi Akımının Analizi”, çev. Ömer Aydın, Journal of Istanbul University Faculty of Theology 5 (Nisan 2012) 169-184; İsmail R. Faruki, Bilginin İslamileştirilmesi: Genel îlkeler ve Çalışma Planı, çev. Fehmi Koru (İstanbul: Risale Yayınlar1, 1985).

4 İslamî perspektifi yansıtan psikoloji çalışmaları bibliyografyası için bk. Amber Haque vd., "Integrating Islamic Traditions in Modern Psychology: Research Trends in Last Ten Years", Journal of Muslim Mental Health 10/1 (Temmuz 2016), 75-100; Ayrıca İslam Psikolojisi bağlamında değerlendirilebilecek diğer bazı araştırmalar için bk. Malik B. Badri, "Psychological Reflections on Ismail Al-Faruqi's Life and Contributions", American Journal of Islamic Social Sciences 31/2 (2014), 145-152; Abdallah Rothman - Adrian Coyle, "Conceptualizing an Islamic psychotherapy: A grounded theory study.", Spirituality in Clinical Practice 7/3 (2020), 197-213; Malik Badri, "The Islamization of Psychology: Its 'Why', Its “What', Its 'How' and Its “Who'”, International Journal of Islamic Psychology 3/1 (2020), 22-33.

5 Hayati Hökelekli, İslam Psikolojisi Yazıları (İstanbul: Değerler Eğitim Merkezi Yayınları, 2017).

6 Habil Şentürk, İbadet Psikolojisi: Hz. Peygamber Örneği (İstanbul: İz Yayıncılık, 2008).

7 Ali Ayten, “Arap Ülkelerinde İslami Psikoloji ve Din Psikolojisi Çalışmaları”, Çukurova Üniversitesi İlahiyat Fakültesi Dergisi 12/2 (2012), 51-98.

8 Zuhal Ağılkaya Şahin, "Müslüman Psikologlar Kertenkele Deliğinden Çıktı M1? İslami Psikoloji Alanındaki Gelişmeler", Journal of Turkish Studies 14/2 (Ocak 2019).

9 Sevde Düzgüner, "Dini Psikoloji ve İslam Psikolojisi Bağlamında Din Psikolojisini Yeniden Düşünmek", İslâmî İlimler Dergisi 12/3 (2017), 133-163.

10 Saliha Uysal, Gelenek ile Gelecek Arasında İslamî Psikoloji (İstanbul: Çamlıca Yayınları, 2021). 
Perspektiften Psikoloji ${ }^{11}$, Gencer'in İslam Psikolojisinde Gelenekler, Paradigmalar ve Temel Kavramlar $^{12}$ gibi tercüme faaliyetleri de mevcuttur.

Bu araştırmada biz, söz konusu çalışmalardan farklı olarak doğrudan modern psikoloji ve İslam bilim birikiminde ortaya çıkan ruhsal alan ile ilgili çalışmaları mercek altına alarak İslamî psikolojinin nasıl şekillenmesi gerektiğini ele almak istiyoruz. Bu bağlamda insanı tanımada kullanılacak temel metot olarak modern psikolojinin İslam dünya görüşüne sahip bireyleri ifade etmede ne derece işlevsel olduğunu tekrar tartışmaya açarak İslamî psikoloji geleneğinin oluşturulmasının 'nasılını' sorgulayacağız. İki aşamadan oluşacak araştırmamızda öncelikle modern psikolojinin İslam dünya görüşüne uyarlanması imkânını, daha sonra sadece İslamî kaynaklara dayanan bir psikoloji geleneğinin oluşturulması imkânını değerlendireceğiz. Bu bağlamda öncelikle önde gelen (Freud, Jung ve Frankl gibi) bazı psikologların insan ve din konusundaki görüşlerini irdeleyecek ve İslamîleştirme şartları bakımından taşıdıkları potansiyeli tartışacağız. Ardından İslam bilim tarihinde psikoloji alanında yapılan çalışmaları ve İslamî kaynaklarda psikoloji bilimine temel oluşturacak dayanakları inşa etkinliğine uygunlukları açısından ele alacağız.

Araştırmada bilgi elde etme sürecinde konuyla ilgili var olan materyallerin sistemli analizini içeren Doküman İnceleme'sini kullandık. ${ }^{13}$ Doküman incelemesi, araştırma verilerinin birincil elden kaynağı sayılan çeşitli dokümanların toplanması, gözden geçirilmesi, sorgulanması ve analizi içeren bir yöntemdir. Dokümanların değerlendirilmesinde tarafsız ve objektif olmaya özen gösterdik. Her çalışma olduğu gibi bu çalışma da ulaşılan kaynak, yorum ve araştırıcının bakış açısıyla sınırlıdir.

\section{Modern Psikolojinin Bilimsel Temel ve Karakteri}

Şüphesiz her bilim insanı içinde yaşadı̆̆ı kültür ve medeniyetin imkân ve sınırları çerçevesinde, çağının ruhuna (Zeitgeist) uygun olarak araştırır ve teorilerini geliştirir. Modern Batı düşüncesi içerisinde gelişen psikoloji biliminin bilimsel temel ve karakteri de bu imkân ve sınırlara tabidir. ${ }^{14} \mathrm{Bu}$ nedenle 'rönesans' ile başlayıp 'aydınlanma’ ile sistemleşen modern Batı düşüncesinin psikoloji alanında izdüşümlerini gözlemlediğimiz temel bazı özelliklerini kısaca ele almak istiyoruz.

Modern bilimin en önemli özelliği insan merkezli bir gerçeklik anlayışına sahip olmasıdır. Kozmolojide "Copernicus devrimi” ile gündeme gelen mekanik evren fikri Newton fiziği ile son şekline bürünürken, belirli yasalara boyun eğmiş evren düşün-

11 Amber Haque, "íslamî Bir Perspektiften Psikoloji ve Din Arasındaki İlişki ve Bütünleşme", çev. Mustafa Koç, Uludağ Üniversitesi îlahiyat Fakültesi Dergisi 20/1 (2011), 227-258.

12 Rasjid Skinner, "İslam Psikolojisinde Gelenekler, Paradigmalar ve Temel Kavramlar", çev. Nevzat Gencer, Hitit Üniversitesi İlahiyat Fakültesi Dergisi 36 (2019), 671-683.

13 A. Hamdi İslamoğlu- Ümit Alnıaçı, Sosyal Bilimlerde Araştırma Yöntemleri (İstanbul: Beta Yayınları, 2019), 228.

14 Medeniyet tasavvuru ve dünya görüşünün bilimsel paradigmaya etkilerini incelemek için bk. Ahmet Davutoğlu, "Medeniyetlerin Ben-idrâki”, Divan: Disiplinlerarası Çalışmalar Dergisi 3 (Aralık 1997), 10; Enver Uysal, Ahlaki Varlk Olarak İnsan (Bursa: Emin Yayınları, 2018), 34. 
cesi insanı da kapsamına alan bir yasalılık fikrine zemin hazırlamıştır. ${ }^{15}$ Söz gelimi aydınlanma döneminde kaleme alınan Makine Insan (L'Homme Machine) ${ }^{16}$ isimli eser bunun en somut ve çarpıcı örneklerinden biridir. Dönemsel atmosferinin kimliğini taşıyan bu çalışmada insan ruhu “aydınlanmış bir makine”ye benzetilirken, insanın psikolojik tabiatı da salt fizyolojik süreç ve dürtülere indirgenmiştir. ${ }^{17}$ Daha sonra modern psikolojide söz sahibi olacak ana akım psikologları, bu düşünce ekseninde insanı mekanik bir aygıt olarak görmüş, onun ruhsal ve manevi boyutlarını deney ve gözlemle sınırlı bir çerçevede incelemeyi yegâne metot kabul etmişlerdir. Ayrıca mekaniklik-belirlenmişlik fikrine bağlı olarak yapılan çalışmalarda elde edilen bulgular, insan tabiatının değişmez yasaları olarak değerlendirilmiştir.

$\mathrm{Bu}$ haliyle Yahudi ve Hristiyan geleneğinden izler taşıyan psikolojinin bilimsel karakteri İslam biliminin ${ }^{18}$ bilimsel karakterinden farklılaşır. Modern psikolojinin yukarıda değinilen paradigma sebebiyle Müslüman bireyin yetiştiği kültürü ifade edememesi problemi ortaya çıkmaktadır. Bazı psikologların İslam inancına ters birtakım teorileri ileri sürmesi de var olan ayrılı̆̆ı derinleştirmiştir. ${ }^{19}$ Yani modern psikologlar insanı nesnelleștirmekle kalmamış, dini ve inançları da bir hastalık belirtisi olarak tanımlamıştır. Bu bakış açısına göre din, doğanın karşı konulamaz güçleri karşısında âciz kalan, dünyadaki haksızlıklara karşı adalet beklentisi içerisinde ve ölüm sonrası hayatın belirsizliğinden ürperen insanın, bu gerilimden kurtulmak amacıyla icat ettiği bir telafi mekanizmasıdır. Bir başka deyişle dinin temeli tatminsizlik, ihtiyaç ve eksiklik duygularıdır. ${ }^{20}$

İște böyle bir dönemde, kültürel bağlamından koparılarak evrensellik iddiası ile insanı inceleyen modern psikoloji ile karşılaşan Müslüman bilim insanları, bu yeni paradigma karşısında iki farklı tutum takınmışlardır. Kimisi ‘Batı'nın ürünü olarak psikolojiyi olduğu gibi kabullenirken kimisi de Müslüman bireyin duygu ve davranışlarını açıklamada yetersiz kaldığı gerekçesiyle onu reddedip İslami kaynakları referans alan Kindî (öl. 260/866), Muhâsıbî (öl. 243/857), Fârâbî (öl. 339/950), İbn Sînâ (öl.

15 Daniel N. Robinson, Psikolojinin Felsefi Tarihi (An Intellectual History of Psychology), çev. Deniz Uludağ (Ankara: Doğu Batı Yayınları, 2020), 421-584; Kasım Küçükalp - Ahmet Cevizci, Batı Düşüncesi: Felsefi Temeller (Ankara: İSAM Yayınları, 2018), 127-131.

16 Robinson, Psikolojinin Felsefi Tarihi, 414'ten aktararak Julien Offray de La Mettrie, L'Homme Machine (Leiden: Elie Luzac Fils, 1748).

17 Schultz - Schultz, Modern Psikoloji Tarihi, 61-81.

18 İslam bilimi karakterini ileride ele alacağı.

19 Malik Babikir Badri, Müslüman Psikologların İkilemi, çev. Aynur Tutkun (İstanbul: Safa Yayın Dağıtım, 2016), 18.

20 Psikolojinin, dinî inanç ve davranışların temeli kabul ettiği içgüdülere cevap verme ve kişiliği bütünleme arayışında tatmin etme özelliklerini Ömer Rıza, farklı bir bakış açısıyla, en doğru dini bulma noktasında psikolojinin sunduğu kriterler olarak değerlendirir. Bu iki kriter doğrultusunda Budizm, Hristiyanlık ve İslam dinini karşılaştırmalı olarak ele almış ve her iki kriteri sağlayan tek dinin İslam olduğu sonucuna ulaşmıştır. bk. Ömer Rıza Doğrul, “İlmü’n-nefs ve Din ”, sad. Hüseyin İbrahim Yeğin, Abant İzzet Baysal Üniversitesi İlahiyat Fakültesi Dergisi 3/5 (Haziran 2015), 260. Orijinali için bk. Ömer Rıza Doğrul, “İlmü'n-nefs ve Din” Sebîlü’r-Reşâd 25/623 (1340/1924), 7-9. 
429/1037) ve Gazâlî (öl. 505/1111) gibi Müslüman düşünürlerin insan tasavvuruna dayanan bir psikoloji inşa etme girişiminde bulunmuşlardır. ${ }^{21}$

$\mathrm{Bu}$ iki farklı tutumdan hangisinin daha elverişli olduğu ise tartışmalıdır. Acaba modern Psikoloji İslamîleșebilir mi? Dinî kaynaklar, insanı konu alacak bilimsel etkinlik için ne kadar uygun? Bu sorulara cevap vermek üzere öncelikle modern psikolojiyi mercek altına almak istiyoruz.

\subsection{Tarihsel Açıdan Psikolojide Temel Yaklaşımlar}

Psikolojinin akademik nitelik kazandığı 18. ve 19. yüzyılın 'aydınlanmacı' öğretileri, 20. yüzyılın ikinci yarısına yaklaştığımızda büyük değişikliklere sahne oldu. Modernitenin meta idealarının karşılık bulmaması ve post modernizmin farklı bilme biçimlerini destekleyen çoğulculuğu bilimsel disiplinlerde de etkisini gösterdi. Bu dönemde insan ve doğası hakkında yapılan araştırmaların derinleşmesi ile evrensellik iddiasında bulunan psikolojinin sosyal ve kültürel bir çevrede yetişen insanı anlamada yetersiz kaldığı ortaya çıktı. ${ }^{22}$ Collingwood'un "yalnızca belirli bir tarihsel dönemdeki koşullarla insan hayatındaki daimî koşulları karıştırma hatası" ${ }^{23}$ şeklinde ifade ettiği evrensellik ve belirlenmişlik fikri kaçınılmaz olarak dönemin çoğulcu karakterine teslim oldu.

$\mathrm{Bu}$ çoğulculuğun kendini gösterdiği alanlardan en öne çıkanı insan araştırmasının çerçevesini çizen kuramlardı. Modern dönemde biyolojik/nörolojik, psikanalitik, davranışçı yaklaşımlar psikoloji sahasından uzun süre hüküm sürdüler. Yukarıda ele aldığımız temeller sebebiyle her biri insan ruhunu farklı bir standartta ele alıyor ancak ulaştıkları bulguları ve ürettikleri bilgileri değişmez gerçeklikler olarak açıklıyorlard1. Ancak süreç içerisinde -post modern Zeitgeist'in da etkisiyle birlikte ${ }^{24}$ - söz konusu yaklaşımlar eleştirilmiş böylece Hümanist, Ben-Ötesi (Transpersonal) ve Pozitif Psikoloji gibi insanı mekanik bir varlık olarak görmeyen yaklaşımlar ortaya çıkmıştır. ${ }^{25}$ Benzer şekilde psikoterapi tekniklerinde revaç bulan Bilişsel Davranış̧̧ı ve daha sonra Budist inancından esinlenen meditasyon içerikli (bilinçli farkındalık, biyoenerji vb.) spiritüel teknikler, mekanik insan fikrinin artık ortadan kalkmaya başladığının göstergesi sayılabilir.

Davranış̧ı, ampirik, analitik metodun hermönetik varyasyonlar taşıyan Hümanist ve Transpersonal örneklerine doğru evriminde ${ }^{26}$ meydana gelen değişiklikleri psiko-

${ }^{21}$ Ali Köse - Ali Ayten, Din Psikolojisi (İstanbul: Timaş Yayınları, 2018), 85; Ekrem Özbay, İslam Psikolojisi ve İslam (Istanbul: IQ Kültür Sanat Yayıncıllk, 2016), 15-20; Muhammed Kızılgeçit, "İzmirli İsmail Hakkı'nın ‘ilmü’n-Nefs'inde Modern Psikoloji Tarihi”, Dinbilimleri Akademik Araștrma Dergisi 13/1 (Şubat 2013), 163.

22 bk. Hayati Hökelekli, “Türkiye'de Din, Dindarlık ve Din Psikolojisi Araştırmaları: Psikolojide Yerelellik ve Evrensellik Tartışmaları Bağlamında Bir Değerlendirme", Dokuz Eylül Üniversitesi îlahiyat Fakültesi Dergisi Din Psikolojisi Özel Sayısı (Nisan 2016), 312.

23 Robinson, Psikolojinin Felsefi Tarihi (An Intellectual History of Psychology), 26. Collingwood'dan alıntılanan bölüm için bk. Collingwood, The İdea of History (New York: Oxford University Press, 1994), 224.

24 Schultz - Schultz, Modern Psikoloji Tarihi, 697.

25 Köse- Ayten, Din Psikolojisi, 12; Hayati Hökelekli, Psikolojiye Giriş (Bursa: Emin Yayınları, 2015), 5-6.

${ }^{26}$ Jacob A. Belzen - Ralph W. Hood, "Methodological Issues in the Psychology of Religion: Toward Another Paradgim?", The Journal of Psychology 140/1 (2006), 12-16. 
logların insan ve din hakkındaki görüşlerinde izlememiz mümkündür. Ancak İslam’a uygunluk için bu paradigma değişimi yeterli mi, sorusu akla gelebilir. Bu nedenle şimdi önde gelen bazı psikologların insan ve din hakkındaki görüşlerini kısaca ele alacak, modern haliyle Psikolojinin İslamîleşme potansiyelini göreceğiz. Bunu yaparken alan ve sınır bakımından ve teorik süreci özetlemedeki yeterliliğine dayanarak sadece Freud (öl. 1939), Jung (öl. 1961) ve Frankl'in (öl. 1997) görüşleri üzerinde duracağız.

\subsection{Bazı Psikologlar Özelinde Modern Psikoloji'nin Evrimi}

Wilhelm Wundt'un (öl. 1920) 1879 yılında ilk psikoloji laboratuvarını kurmasından günümüze uzanan süreçte insan, din ve tanrı konularını ele alan birçok şahıs, kuram ve görüş ortaya çıktı. Hatta W. James ile insanın dini duygu ve davranışını spesifik araștırma alanı olarak belirleyen Din Psikolojisi bilimsel bir disiplin haline geldi. Ancak biz metodolojik dönüşümü görmek adına burada öncelikle Freud'u ele almak istiyoruz.

Freud'a göre insan zihninin bilinç, bilinç öncesi ve bilinçaltı şeklinde üç boyutu ${ }^{27}$ vardır ve her bir insan davranışı bu bilinç boyutlarıyla ilişkilidir. Bu boyutlardan yola çıkarak insan doğasını tanımlamak amacıyla kendi 'kişilik kuram'ını geliştirir. ${ }^{28}$ Kişilik kuramının temelinde, insan davranışlarından her birinin bastırılmış bazı güdülere dayandığı varsayımı yatar. Ona göre, insanı harekete geçiren baş̧lca iki dürtü, yaşam içgüdüsü (life instict)-libido ve ölüm içgüdüsü (death instict)-saldırganllk dürtüsü aynı zamanda psikotik ve nevrotik rahatsızlıkların da kaynağıdır. ${ }^{29}$ Toplumsal bir ortamda bu güdülerin açıkça tatmin edilmesi hoş karşılanmadığı için doyurulamamış her türlü dürtü bilinçaltına itilir ve dil sürçmeleri, rüya gibi süreçlerle şuur üstüne çıar. Onun kişilik teorisinde bu ilkel güdülere 'id' denir. Akla tekabül eden ego ve ben idealine karşıllk gelen süper ego ile kişi, bu dürtüleri kontrol edebilirse ruhsal hastalıkların önüne geçilebilir. Bastırılmış dürtülerin kontrolü kadar niçin ve hangi nedenle bastırıldıkları da önem taşır. Dikkatini bu bastırma kuvvetlerine yönelten Freud, ruhsal hastalıkları oluşturan kaynaklardan birinin din olduğu sonucuna ulaşmış, din ile obsesif bozukluklar arasında ilişki kurmuştur. ${ }^{30}$

Ona göre din, çocukluk döneminde yaşanan oedipus ${ }^{31}$ ve electra ${ }^{32}$ gibi komplekslerden ve insanın doğa olayları karşısındaki çaresizliğinden ileri gelir. Bu nedenle dini, ruhsal bir saplantı rahatsızlığı (nevroz) olarak tanımlamıştır. Dini obsesif bozuk-

27 Calvin S. Hall, Freudyen Psikolojiye Giriş, çev. Ersan Devrim (İstanbul: Kaknüs Yayınları, 2016), 55-59. Freud buna topoğrafik kuram ismini verir.

28 James Forsyth, Psikolojik Din Kuramları, ed. Mustafa Ulu (Kayseri: Kimlik Yayınları, 2017), 12-14.

29 Ali Köse - Ali Ayten, “Sigmund Freud”, Doğu'dan Batı'ya Düşüncenin Serüveni (İstanbul: İnsan Yayınları, 2017), 603-613.

30 Ali Ayten, Psikoloji ve Din: Psikologların Din ve Tanrı Görüşleri (İstanbul: İz Yayıncılık, 2010), 42-46.

31 Kişinin çocukken annesine âşık olması ama toplumsal baskı sebebiyle bunu açığa çıkaramaması ve babasından bu nedenle nefret etmesini ifâde eden bir komplekstir. Anneye sahip olma ve babayı öldürme suçlarını işleyen Oedipus, Freud nazarında dinin, ahlakın, sanatın ve tüm kültürel faaliyetlerin kaynağıdır.

32 Oedipus'un kızlardaki karşıllı̆̆ı. 
luk, bebeklik arzularının tatmini, bazen de bir illüzyon olarak değerlendirmesi; insanı bilinçaltındaki cinsellik ve saldırganlık dürtülerine boyun eğerek özgürlüğünü kaybetmiş bir varlık olarak tarif etmesi ${ }^{33}$; kuramını yalnızca hasta kişiler üzerinde yaptığı incelemeler neticesinde oluşturması bahsettiğimiz ampirik-analitik metodu çok iyi örneklendirir. ${ }^{34}$ Daha yalın bir şekilde ifade edecek olursak Freud, insanı bir doğa bilimcinin dünyayı ele alması gibi nesnelleștiren bir yaklaşımla ele almıştır. Neticesinde ruhsal hayat ve maneviyatın dini içeriklerinin anormal durumlarla ilişkilendirilmesi de kaçınılmaz olmuştur. Freud'un sunduğu insan psikolojisinin bu eksik ve kimilerine göre hatalı yorumu kısa süre içerisinde eleştirilmeye başlamıştır. Bu eleştiriyi yöneltenlerden biri de psikanalizin ilk öğrencilerinden olan Jung 'tur.

Jung, 'libido' kavramını 'ruhsal enerji' olarak değerlendirmesi; mitoloji, antropoloji, dinler tarihi ve uzak doğu dinleri ile ilgilenmesi bakımından Freud ve psikanaliz kuramından ayrılan ilk psikologlardan biridir. İnsan doğasını nitelemede yetersiz gördüğü Freud'un 'kişilik teorisi’ yerine ‘arketipler' ve 'bilinçdışı'nı temel alan yeni bir anlayış geliştirmiştir. Bu anlayışa göre 'kişisel' ve 'kollektif' olmak üzere iki tür bilinçdışı vardır. Kişisel bilinçdışında, kişinin unuttuğu ya da bastırdığı bireysel yaşantılar; kollektif bilinçdışında ise insanlığın tarihin başlangıcından itibaren biriktirdiği mitolojik karakterli içerikten oluşan arketipler bulunur. Arketip, insanın kalıtımsal olarak sahip olduğu psişik içeriklerdir ve din de bunlardan biridir. ${ }^{35}$ Farklı dinlerde benzer kavram ve olayların anlatılması bu kalıtımsal arketipler ile açıklanır. Bu açıklamasıyla Jung, dini, psikolojik bir sürece indirgemiş, aynı zamanda onu bilinçdışına hapsetmiştir. ${ }^{36}$ Ancak bireyleşme olarak nitelendirdiği süreçte ona göre din her halükârda verimli bir unsur olarak iş görür. Bireyleşme (individuation), 'psikolojik bireyin' kollektif psikolojiden farklılaştı̆̆ı psikolojik bir gelişimdir. ${ }^{37}$ Bireyleşme sürecinde kendi öznel psikolojik varlığını genel psikolojiden ayırt eden insan, kolektif bir yapının parçası olduğunun farkına varır. Bir bakıma bu, bilinç ile bilinçdışının buluşmasıdır. Ciddi dönüşümleri meydana getiren bu süreç Jung'a göre doğal bir gerekliliğe dayanan dinî bir serüvendir.

Jung nazariyesinde din, psikoterapi sistemlerinin en gelişmişi olarak görülür. Dini, fonksiyonel bir bakış açısıyla değerlendirmiştir. Her ne kadar Freud ile karşılaştırıldığında dinin gerçekliğini psikoloji ile uzlaştıran bir tutum ${ }^{38}$ içerisinde olsa da

33 Forsyth, Psikolojik Din Kuramları, 27-47.

34 Habil Şentürk, "Freud'un Psikoloji ve Din Anlayışına Eleştirel Bir Yaklaşım”, Dini Araştırmalar 7/19 (Haziran 2004), 226-229. Freud'un din hakkındaki görüşleri için bk. Sigmund Freud, Din, çev. Nursel Y1ldız (İstanbul: KafeKültür Yayıncılık, 2015); Sigmund Freud, Totem and Taboo (London: Penguin Freud Library, 1990); Sigmund Freud, Moses and Monotheism, çev. Katherine Jones (London: Hogarth Press, 1939).

35 Forsyth, Psikolojik Din Kuramlar, 96-114; Ayten, Psikoloji ve Din, 67-76.

36 Ali Ulvi Mehmetoğlu, “C. G. Jung’un Tanrı Anlayışı”, Toplum Bilimleri Dergisi 7/14 (2013), 20.

37 C.G. Jung, Analitik Psikoloji Sözlüğü, çev. Nur Nerin, (İstanbul: Pinhan Yayıncıllk, 2016), 17.

38 Jung'un İslâm dininin temel kaynakları ve kültür ögelerini psikanalitik bakış açısıyla değerlendirmesini konu edinen çalışmalar için bk. Abdurrahman Kasapoğlu, Carl Gustav Jung'un Kehf Suresi Tefsiri (Malatya: Huzur Matbaa, 2006); İbrahim Gürses, “Jung'cu Arketip Teorisi Bağlamında Tasavvufî Öykülerin Değerlendirilmesi: Sîmurg Örneği”, Uludağ Üniversitesi İlahiyat Fakültesi Dergisi 16/1 (Ocak 2007), 77-96. 
dindarlığı psikolojik şartların sonucu olarak değerlendirmesi, ruhsal olanla (dini tecrübe) psikolojik olanı birbirine karıştırıp kutsallığı ortadan kaldırmasına neden olmuştur. Yani din herhangi bir psişik içerikten başka bir şey değildir.

Jung sonrası gelişen psikoloji kuramları insan ile din ilişkileri açısından dikkate alındığında daha uyumlu bir karaktere sahip oldukları görülür. Sözgelimi dine, yine fonksiyonel bir bakış açısıyla yaklaşan Fromm'un (öl. 1980) sevgi, hakikat ve kendini gerçekleştirmeyi esas alan 'hümaniter ${ }^{39}$ ve Maslow'un (öl. 1970) dinî tecrübenin evrenselliğini savunan ' $m i s t i k^{40}$ din anlayışında insan, bilinçaltı ve bilinçdışı süreçlere boyun eğmemiş, özgür bir varlık olarak değerlendirilir. Biz, bu süreç içerisinde dinin kutsal yönünü parantez içine almayan Frankl'ın insan ve din hakkındaki görüşlerini kısaca ele alarak modern psikolojinin gelişim sürecinde meydana gelen dönüşümleri görmeye çalışacağız.

Frankl'a göre insan -Freud ya da Jung'da olduğu gibi- bilinçaltı/-dışı süreçlerin güdülemesine itaat eden, iradesi elinden alınmış bir varlık değildir. 0 , kendi hayatına dair karar verebilen irade sahibi bir varlıktır. ${ }^{41}$ Bunu kendisi 'Makine modeline bağh bazı psikologlarda insani varlığın insani niteliği göz ardı edilmiş ve boşlanmıştır. ${ }^{42}$ şeklinde ifade eder. Nazi kamplarında her türlü acı ve sıkıntıya rağmen hayata tutunan insanları gördüğünde insanın hayattaki temel motifinin anlam istemi olduğu sonucuna ulaşmıştır. Bu doğrultuda Husserl'in hermenötik psikoloji eleştirisine benzer bir Tiefenpschologie (derinlik psikolojisi) eleştirisinde bulunur. ${ }^{43}$ Logoterapi adını verdiği terapötik tekniği ile analitik psikolojide yeni bir sayfa açan Frankl 'terapi yoluyla anlam' anlayışını 'anlam yoluyla terapi' ilkesi ile değiştirerek ${ }^{44}$ farklı anlam içeriğine sahip olan tüm dinî ve manevî öğretilere de bir şekilde kapı aralamıştır. Tanrı ve din hakkındaki görüşleri de oldukça ilginçtir.

Frankl, tanrı ile insan ilişkisi bağlamında Tanrı'nın aşkın karakterini dikkate alarak insanın tanrısal boyuta ulaşamayacağını 'Gizli Tanrı' kavramıyla ifade eder. Bu

39 Fromm dini, hümaniter ve otoriter olarak ikiye ayırır. Otoriter din kurumsallaşmış baskıcı; hümaniter din ise sevgi, kuşatıcılık ve özgürlüğü temel alan bir dindir. Ona göre dinlerin ruhsal gerçekliği aşan bir tarafı yoktur. En gerçek din; 'insanlara kendilerini adayabilecekleri bir hedef ve ortak bir davranış biçimi sunan düşünce sistemi'dir. Tek Tanrılı dinlerin öngördüğü din tanımının tüm dinleri kapsamadığını düşünür. Ona göre insanlar gelecekte evrensel nitelik taşıyan bir dine inanacaktır. Ayten, Psikoloji ve Din, 107-113.

40 Maslow'a göre iki tür din; kuralcı ve mistik ve buna bağlı olarak iki tür dindarlık vardır. Birincisi, kuralcı dine bağlı 'düzen insanı', ikincisi kuralcı olmayan dine bağlı 'mistik insan'. 'Varlık değerleri'ne sahip, ihtiyaçlar piramidinin en üst seviyesine ulaşmış yani kendini gerçekleştirmiş mistik insanın, Tanrı'ya inansın ya da inanmasın dindar bir insan olduğunu düşünmektedir. Ayten, Psikoloji ve Din, 138-143.

${ }^{41}$ Victor Frankl, Psikoterapi ve Din: Bilinçdışındaki Tanrı, çev. Zeynep Taşkın (İstanbul: Say Yayınları, 2014) 21; Victor Frankl, Der unbewußte Gott: Psychotherapie und Religion (München: dtv Verlagsgesellschaft $\mathrm{mbH}, 2017), 17$.

42 Victor E. Frankl, Anlam İstenci: Logoterapinin Temelleri ve Logoterapi Uygulamaları, çev. Mustafa Yalçınkaya (İstanbul: Öteki Yayınevi, 2018), 27-28.

43 Viktor E. Frankl - Veysel Atayman, Hayatın Anlamı ve Psikoterapi (İstanbul: Say Yayınları, 2019), 233.

44 Abdülkerim Bahadır, "Psikoterapi'de Yeni Bir Yaklaşım: Logoterapi ve Viktor Frankl”, Uludağ Üniversitesi İlahiyat Fakültesi Dergisi 9/9 (Ocak 2000), 471. 
ilişki kişisel bilinçdışında gerçekleştiği için tanrı aynı zamanda 'Bilinçdışı Tanrı' ${ }^{45}$ şeklinde kavramlaştırılır. Tanrıyla olan bu ilişkiye de ‘Bilinçdışı Dindarlık' denir. O, dinleri, her biri aynı varoluşsal boşluğu dolduran farklı hakikatler olarak görür. Bir dinin diğerine bu açıdan bir üstünlüğü yoktur.

Genel olarak Frankl'ın insanı birtakım biyolojik ve fizyolojik faktörlerin güdümünde hareket eden mekanik bir aygıt yerine tercih imkânı saklı, anlam motifini temel alan bir varlık olarak görmesi ve dinin kutsal boyutunu paranteze alan psikolojik kuramlardan farklı olarak dinin aşkınlığını kabul etmesi, modern disiplin olarak psikolojinin determinist ve pozitivist/ateist karakterden sıyrılabileceğini göstermesi bakımından oldukça önemlidir.

\subsection{Modern Psikolojinin Değerlendirilmesi}

Modern bilim disiplinlerinde geçerli olan insan doğası ve din hakkındaki yorumlar, psikoloji bilimi özelinde görüldüğü üzere birtakım değişikliklere tanıklık etmiştir. Freud'un insanı otomatik ve mekanik bir aygıt şeklinde tarif etmesinden Frankl'ın anlam arayışındaki insan anlayışına kadar geçen süreçte, insanın biyolojik, fizyolojik ve psikolojik gerçekliği yanında spiritüel/aşkın bir yönü olduğu da bilimsel paradigma tarafından kabul edilmiştir. Bu gelişmeler doğrultusunda psikoloji, tek tip ama evrensel bir karakterden uzaklaşarak kültürlerarası farklılığı dikkate alan ve insanının aşkın boyutunu inkâr etmeyen bir bilim disiplini haline gelmiştir. Aynı gelişmeyi bir başka açıdan Davranışçı kuramdan Bilişsel Davranışçı ya da Trans-personel psikoloji kuramlarına doğru evrilen gelişmelerde de gözlemlememiz mümkündür. Aşkın alanla ilişki ve o alandan gelen bilginin değer kazanması, psikolojide İslam dünya görüşüne uygun temellendirmelerin önünü açabilir. Bu bağlamda Hristiyan Psikolojisi, Yahudî Psikolojisi, Budist Psikolojisi gibi teolojiyi temel alan birçok girişim zaten söz konusu süreçte gündeme gelmişti. ${ }^{46}$ Ancak deneysel ve bilimsel sınırlarda kalarak tamamen vahyi merkeze alan bir dünya görüşünü telif etmenin güçlükleri de yok değildir. Bu güçlüklerin ardında insan merkezli olan bilimsel paradigmanın geçerliliğini hala koruması yatmaktadır. İnsan merkezlilik psikolojinin İslamîleşme potansiyelini zayıflatan faktörlerin başında gelmektedir. $\mathrm{Bu}$ nedenle tüm olumlu gelişmelere rağmen tamamen İslamî kaynakları referans alan bir psikoloji bilimi oluşturulmalı görüşünü savunanlar hala vardır. ${ }^{47} \mathrm{O}$ halde İslamî kaynaklar açısından da durumu ele almamız gerekir.

Peki, bu ne kadar mümkün? Vahyin belirlediği ilkelerle bilimsel bir metot geliştirilebilir mi?

45 Frankl'ın kullanmış olduğu bilinçdışı kavramı ve tanrı-insan ilişkisi anlayışı, Jung'un bilinçdışı ve tanrı fikirlerinden farklıdır. Jung, kolektif bilinçdışında psişik bir içerik olarak Tanrı'yı insan için kabul edilmesi zorunlu bir varlık olarak görürken Frankl, Tanrı'yı bilinçdışı bir içerik olarak görmez ve insanın bilinçdışı tarafından kaderi belirlenmiş bir varlık olduğu fikrini reddeder. 'Tanrı kendisini, bireyin bilincinde düşünülmesi gereken bir zorunluluk olarak değil, düşünülebilecek bir imkân olarak gösterir.' Bahadır, "Psikoterapi'de Yeni Bir Yaklaşım”, 479.

46 Sevde Düzgüner, "Dini Psikoloji ve İslam Psikolojisi Bağlamında Din Psikolojisini Yeniden Düşünmek", İslâmî îlimler Dergisi 12/3 (2017), 155.

47 Özbay, İslam Psikolojisi ve İslam, 15-23; Badri, Müslüman Psikologların İkilemi, 23-24. 


\section{2. İslam Biliminin Temel Karakteri ve İslamî Kaynaklarda Psikoloji}

İnsan ve toplum bilimlerinin fen bilimleri ile yaptıkları inter-disipliner çalışmalar doğrultusunda insan; biyo, psiko, sosyo ve spiritüel bir varlık olarak tanımlanmıştır. Varlıksal bütünlüğü içerisinde insanın ele alınmasının, psikoloji tarihi açısından oldukça uzun bir zaman dilimine ihtiyaç duyduğunu gördük. Her şeye rağmen kutsal ve maneviyatın insanın varoluşsal niteliklerinden biri olduğunu ifade edecek duruma geldiğimizi söyleyebiliriz. Ancak İslam inancına göre şekillenecek bir bilim için bu yeterli olmayabilir. Çünkü İslam inancına göre oluşturulacak bilimsel metodun kavram ve ilkeleri ya doğrudan vahiy ile Tanrı'dan ya da vahiyde gizlenen işaretlerin yorumundan alınmalıdır. Zira İslam bilim karakterinin en önde gelen özelliği vahiy ve tevhit ilkesine göre şekillenmiş olmasıdır. ${ }^{48} \mathrm{Bu}$ ilkeye göre âlem, Yaratıcı'nın isim ve sıfatlarının tecelli ettiği bir mekân, insan da O'nun halifesi ve var ettiği en değerli varlıktır. Dikkat edilirse Tanrı'yı merkez alan bir dünya ve insan görüşü hakimdir. Dolayısıyla bilime konu olacak evren ve insan araştırması da kaçınılmaz olarak vahiy yoluyla Tanrı'ya bir atıf içermek durumundadır. Şimdi şu soruyu sorabiliriz: İslam bilim karakteristiğinin tevhit ve vahiy merkezli olma ilkesine göre bir psikoloji disiplini oluşturulabilir mi? Eğer oluşturulabilirse nasıl?

Her konuda olduğu gibi psikoloji konusunda da ilk bakacak olduğumuz temel kaynaklar Kur'an ve sünnet daha sonra tarihsel süreçte karşımıza çıkan yorumlar olacaktır. Ancak hemen ifade etmeliyiz ki Kur'an, her ne kadar insana hitap etmesi ve insanı merkeze alması dolayısı ile insan doğa ve psikolojisine dair birtakım bilgileri ihtiva etse de bilimsel bir tasnif ve yöntemi esas alan ve bu amaca yönelik indirilmiş bir kitap değildir. Bu nedenle biz burada Kur'ân'a, bilimsel bir metin gibi yaklaşmayacak, insani bir teşebbüs olan bilimsel etkinliğe kaynaklık etme işlevselliği yönünden değerlendireceğiz.

Bu bilinç ile Kur'an'a baktığımızda insanın doğasını, nefsin çeşitli hallerini, sapma ve hastalıkların nedenlerini, arınma, terbiye ve tedavi yollarını içeren birçok âyetin ${ }^{49}$ ve bunlara işaret etmek için kullanılan nefs, ruh, kalb, lübb, fuâd ve fitrat gibi birçok kavramı ${ }^{50}$ var olduğunu görürüz. Kavramsal analiz, İslam'ın insan görüşünü tespit etmemize ve böylece İslamî psikolojisinin -var ise- niteliğini ortaya çıkarmamıza yardımcı olabilir. Bu nedenle kavramsal analiz yöntemini esas alarak konuya açıklık getirmeye çalışacağız.

İnsanın "spiritüel" boyutunu ifade eden kavramlardan biri kalptir. Kalp daha çok hayat kaynağı, canlılık ve tüm organların yönlendiricisi olma gibi anlamlara gelir. ${ }^{51}$

İnsan düşünce ve davranışın yönetildiği merkez olarak da değerlendirilir. Bu nedenle Kur'an'da akletme/düşünme fiili kalbe izafe edilmiştir. ${ }^{52}$ İngilizcedeki ration ve

\footnotetext{
48 Osman Bakar, İslam Bilim Tarihi ve Felsefesi, çev. Işık Yanar (İstanbul: İnsan Yayınları, 2016), 18.

49 Necâtî, Kur'an ve Psikoloji, 14.

50 el-Bakara 2/97, Âl-i İmrân 3/7, Hûd 11/120, el-Enbiyâ 21/56, el-Furkân 25/67, et-Tahrîm 66/12.

51 Fatma Çalık, “Bir Semantik Analiz Denemesi: Kur’ân'da 'Kalp' Kavramı”, Uludağ Üniversitesi İlahiyat Fakültesi Dergisi 20/2 (Haziran 2011), 167-190; Hökelekli, İslam Psikolojisi Yazıları, 43-60.
} 
intellect arasındaki ayrımı ${ }^{53}$ hatırladığımızda kalbin eylemi olarak akletmenin evrensel bir olgu olarak insanın var oluşunda köklü bir yere sahip olduğunu söylememiz mümkündür. Bu sezgisel düşünme vasıtası ile insan Tanrı ile iletişime geçer. Bir başka kavram olan lübb, sözlükte öz anlamına gelir ve kutsal nurla aydınlanmış akıl anlamında kullanılır. ${ }^{54}$ Fuâd ise gönül ve ilahî nurların tecelli ettiği yerdir. En önemli kavramlardan biri de şüphesiz ki fitrattır. Fitrat, insanın doğal inanma yeteneği, bir başka deyişle onun yaratıcısına meyilli tarafıdır. İnsanın özünde saf ve temiz olduğunu, doğruyu ve hakikati kabullenmeye elverişli olduğunu ifade eder. Ancak tüm bu kavramlar arasında insanın psikolojik yönünü yani psikolojinin psyche'sine karşılık gelebilecek -ki bir eşleştirme yapma niyetimiz yoktur- kavram olarak nefs ve ruh kavramları öne çıkar. Bu nedenle daha çok nefs ve ruh kelimeleri üzerinde durulması gerekir.

Sözlükte 'bir şeyin kendisi, zâtı, ash, hakîkati ve ruh' gibi anlamlara gelen 'nefs'55 kelimesi, Kur'ân'da üç yüze yakın ayette, Mehmet Ali Aynî’nin tespitine göre sekiz farklı anlamda kullanılmıştır. Kimi zaman mutlak kimi zaman birtakım isim ve sıfat tamlamaları şeklinde karşımıza çıkan nefs kelimesi, bu tasnife göre Kur'ân'da Allah'ın zâtı, hayat kaynağı olan ruh, kalp/sadır, insan bedeni, bedenle beraber ruh, insanın kötülüğe meyilli fitratı, genel anlamda zât ve cins anlamlarına gelmektedir. ${ }^{56}$ İnsan doğasını niteleyici özellikteki âyetleri incelediğimizde nefsin daha çok ruh ve bedenden oluşmuş insan yapısını ifade ettiği açıkça görülür. ${ }^{57}$ Ben olma bilincine sâhip canlı özneyi ifade eden nefs, ruhsal hayatın temel ögesi, algıların, eylem ve ilişkilerin merkezi olarak tarif edilir. ${ }^{58}$ Nefsin hem beşerî, dürtüsel hem de aklî, ilkesel olmak üzere iki boyutu vardır. ${ }^{59}$ Tensel ve tinsel kuvvelerin toplandığı merkez olması aynı zamanda nefsi bir gerilim merkezi kılar. Ruhsal hastalıkların, anksiyete ve duygu durumu bozuklarının kaynağı da nefsin bu gerilimli tabiatıdır. ${ }^{60}$ Belirli bir amaç ve gaye doğrultusunda indirilmiş olan Kur'ân bu gerilimden kaçınması için insanı uyarır, dini ritüeller -zikr ${ }^{61}$, namaz ${ }^{62}$, oruç ${ }^{63}$ gibi ibadetler- ile arınıp, hayatına yön vermesini ondan talep eder. ${ }^{64}$

52 el-A‘râf 7/179.

53 Ration daha ziyâde mantıksal bir düşünme formuna karşılık gelirken; intellect, sezgisel düşünme kâbiliyeti anlamına gelir.

54 Süleyman Uludağ, "Lübb”, Türkiye Diyanet Vakfi İslâm Ansiklopedisi (İstanbul: TDV Yayınları, 2003), 241.

55 İbnü'l-Manzur, Lisânü'l-Arab XVI (Beyrut, 1994), "Nefs”, 238. Kur'an'da nefs lafzının kullanımı ve semantik bir incelemesi için bk. Regis Blachére, “'Nefs' Kelimesinin Kur'an'da Kullanışı Hakkında Bazı Notlar”, çev. Sadık Kılıç, Atatürk Üniversitesi İlahiyat Fakültesi Dergisi 5 (Haziran 1982), 189-196.

56 Mehmet Ali Aynî, “Nefs Kelimesinin Manaları”, Darülfunun İlahiyat Fakültesi Mecmuası 1/14 (1930), 4652, Hökelekli, İslam Psikolojisi Yazıları, 44.

57 bk. el-Bakara 2/48,123,233; Âl-i İmrân 3/25,30; el-Mâ’ide 5/32; el-En‘âm 6/70, 151.

58 bk. el-Bakara 2/130, 187; Âl-i İmrân 3/145, 185; el-En'am 6/98. Hökelekli, İslam Psikolojisi Yazıları, 46.

59 bk. el-Bakara 2/ 30-32. Hökelekli, İslam Psikolojisi Yazıları, 14.

60 Kur'ân'da insan yapısı ve ruhsal hastalıkları hakkında araştırma için bk. Hayati Aydın, Olumsuz Ruh Halleri ve Davranışları Yönüyle Kur'an'da İnsan Psikolojisi (Ankara: Fecr Yayınları, 2016), 358.

61 el-Hicr 15/98, Tâhâ 20/130, en-Nasr 110/3. 
Kur'an'da geçtiği üzere nefsin farklı mertebe ve özellikleri vardır. Emmâre ${ }^{65}$, Levvâme $^{66}$, Mülhime ${ }^{67}$, Mutmeinne ${ }^{68}$, Râziyye ve Merziyye ${ }^{69}$ olmak üzere bunları altıya ayırabiliriz. Bazıları tek sayı elde etmek için bunlara Kâmileyi ekleyerek yedili bir tasnif yapar. Emmâre, nefsin kötülüğe yatkın, ilkel dürtü ve isteklere boyun eğebileceği ve de çoğunlukla eğdiği bir merhaledir. Her insanın özünde var olan sonsuzluk, cinsellik gibi motivasyonların kaynağıdır. Levvâme merhalesinde kişi kusurlarının farkına vararak kendisini hesaba çeker. Akıl ve vicdanın devreye girmesi ile ilkel dürtülerinin kendisini sürüklediği günahlara hayıflanır. Mülhime ise nefsin iyi ve kötü kişilik özelliklerini aynı derecede gerçekleştirme imkânına sahip olduğunu ifade eder. İnsan ne doğuştan iyi ne de doğuştan kötüdür. Bilinçli ve özgür bir varlık olarak iyiyi seçebilir, şayet kötüyü tercih ettiyse hatasını anlayıp bundan dönebilir. Mutmainne nefsin bir denge, kararlık ve huzura kavuşmasıdır. Düşünce ve davranışlarını kontrol edebilir, kişilik bütünlüğünü koruyabilir, varoluşsal tatmin duygusunu yaşayabilir bir konumdadır. Râziyye merhalesinde nefs her hâlükârda Allah'tan gelene rıza gösterir. En ağır sıkıntılarda dahi Allah'tan memnundur. Merziyye onun bir üst aşaması, Allah'ın kendisinden razı olması durumudur. Esasen tüm bu kavramlar nefsin farklı aşamaları olarak değil de farklı özellikleri olarak değerlendirilmelidir. Çünkü hayat oldukça dinamik ve hayat tecrübeleri oldukça değişkendir. İnsan bazı durumlarda dürtüsel bazı durumlarda ülküsel hareket edebilir.

İnsanın psikolojik boyutunu ifade eden bir diğer kavram 'ruh'tur. Sözlükte 'esinti, serinlik, rahmet, sürûr, düşünce, can, rahatllk ve dinlenme' gibi anlamlara karşllı gelir. ${ }^{70}$ Ancak Kur'ân'da, Cebrâil, Îsâ, canllara hayat kaynağı olan kuvvet, vahiy, yel, hayat gibi anlamlarda kullanılmış, hiçbir âyette insanın bireysel varlığını ifade eden bir kavram olarak zikredilmemiştir. ${ }^{71}$ Ayrıca ruhun Allah'ın işlerinden bir olgu olduğu insanların bu konuda çok az bilgiye erişebilecekleri belirtirmiştir. ${ }^{72}$ Başka bir ayette ise insan ruhunun yine mahiyeti bilinmemekle birlikte ìlahî ruhtan bir parça olarak insana üfürüldüğünden bahsedilir. ${ }^{73} \mathrm{Bu}$ üfürülen ruh, fitrat şeklinde isimlendirilen temel inanma kabiliyetinin de dayanağını oluşturur. Her ne kadar Kur'an'da doğrudan psikolojik bir anlam içeriğine sahip olarak geçmese de insanın kutsalla ilişkisini ifade etmesi ve hayat kaynağı olarak tarif edilmesi, ruhu, psikoloji araştırmasında önemli bir konuma getirir.

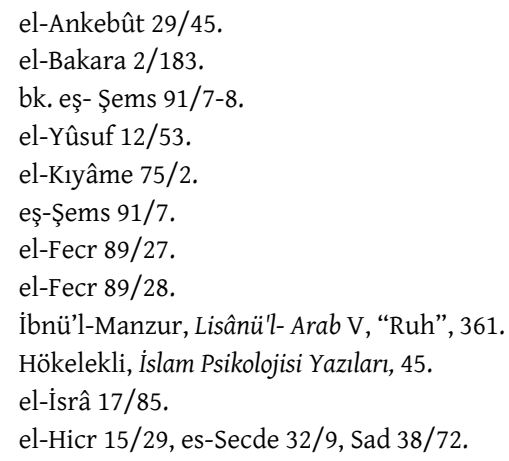


Yukarıda değinmiş olduğumuz kavram ve yaptığımız açıklamaların yanında diğer bir dinî kaynak olan hadislerde bunlara ek olarak rüya, nefsin tabiatı ve güdüleri, kişilik ve yapısı, ruh sağlı̆̆ ve psikoterapik yöntemleri ihtiva eden birçok bilgi bulunmaktadır. Ayrıca ilk vahyin sadık rüyalar şeklinde gelmesi, Peygamberin insanların psikolojilerine uygun davranışlarda bulunması, psikolojik ihtiyaçlar, ruh sağlığı ve psikoterapiyle ilgili rivayetler de hadislerde psikolojik bir insan tasavvuru olduğuna dayanak teşkil eder. $^{74}$ Ayrıca bir hadiste, Kur'an'daki anlamına uygun olarak insanın şekil ve bedenen yaratılışından sonra kendisine ruh üfürüldüğünden söz edilmektedir. ${ }^{75}$

Tüm bu anlatılanlara göre insan hem beden hem ruh itibariyle yaratılmış bir varlıktır ve içerisinde İlahî kıvılcımdan bir pay taşır. İnsanı konu edinen bilimsel çalışmanın birincil kaynağı da ya doğrudan Yaratıcı'nın verdiği bilgiler ya da bunların işaret ettiği yorumlardır. Bu bakış açısına göre insanın ruhsal hayatını anlamak ve ruh sağlığını korumak için en bütüncül ve sistemli bilgi bizzat yaratıcının verdiği bilgiler olarak kabul edilir. Arap akademyasında kaleme alınan birçok psikoloji eserinde söz konusu bakış açısını görmek mümkündür. ${ }^{76} \mathrm{Bu}$ tür eserlerde modern teori ve pratik uygulamalar İlahî kaynaktan beslenmedikleri sebebiyle eksik bulunarak eleştirilir, akabinde Kur'an ya da hadislerden bazı alıntılar yapılarak konu açıklanmaya çalışılır.

Gerek Kur'an gerek hadislerde yer alan insan tabiatına dair bilgilerin, bilimsel bir paradigma geliştirmek için ne kadar elverişli olduğu tartışmaya açık bir konudur. Dini kaynakların doğrudan bilimsel ilkeler oluşturmaya yönelik ortaya çıkmadığı hatırda tutulmalıdır. Yine de bu kaynaklardan yararlanılması insan ve tabiatına İslam'ın gözünden bakabilme imkânı bulmak adına faydalı ve kimilerine göre gereklidir. Ancak buraya kadarki açıklamaları dikkate aldığımızda sadece Kur'an ve hadislere dayanan; inanç ilkelerini kabullenmeyi ve bunları davranışa dönüştürmeyi ruh sağlı̆̆ı ile özdeşleştiren bir anlayışla insanın evrensel tabiatını ifade eden bir bilimsel disiplinin oluşturulamayacağı ifade edilebilir. Paradigmatik olarak dinin emirleri ile aklın gerekliliklerinin birbiriyle çelişmediğini kabul eden bir anlayışla değerlendirdiğimizde ise Kur'an ve hadislerin sunduğu insan görüşünün psikolojiye kazandırılmas1 yöntemiyle insan merkezli ile vahy merkezli olma arasındaki gerilim ortadan kaldırılabilir. Yani teknik olarak psikolojinin yöntemleri kullanılırken ontik ve epistemolojik sınırlar İslam'ın sunduğu perspektife doğru genişletilir.

\subsection{Erken Dönem Müslüman Âlimlerinde Psikoloji}

İslâm bilim geleneğinde psikolojiye dair ilk bilimsel nitelikte fikirler felsefenin Arapça'ya çevrilmesi sonrasında gerçekleşmiştir. Eflâtun'un Phaidon, Timaios ve Politea

74 Osman Necâtî, Hadis ve Psikoloji (Ankara: Fecr Yayınları, 2016), 19, 170-188, 231, 261.

75 "Sizden birinizin yaratılışı ana karnında 40 günde toplanır. Sonra o kadar zaman içinde asılı kan pıhtısı halini alır. Sonra yine o kadar zaman içinde hilkati belli belirsiz bir çiğnem ete dönüşür. Sonra bir melek gönderilir de ona ruh üfler." Müslim, "Kitâbü'l-Kader", Sahîh (Kâhire: Dârü's-Selâm, 1956), 2036.

76 Örneğin: Semih el-Âtıf ez-Zeyn, Ma'rifetü'n-Nefsi'l-İnsâniyye (Beyrut: Dârü'l-Küttâbi'l-Lübnânî, 1991). 
gibi ruh hakkındaki diyalogları yanında Aristo'nun De Anima'sı, Kîndî, Fârâbî ve İbn Sînâ gibi Müslüman düşünürler tarafından yorumlanarak dinî bir çerçeveye yerleştirilmiştir. ${ }^{77}$ İslam bilim birikimi açısından psikolojiyi incelemek için Müslüman dünya görüşünü yansıtan bu şahısların insan psikolojisiyle ilgili görüşlerinin de ele alınması gerekir.

Aristo'nun 'De Anima/Ruh Üzerine' isimli eseri birçok Müslüman filozof tarafindan 'Kitâbü'n-Nefs' ismiyle tercüme ve şerh edilmiştir. Aristoteles'in 'ruh' anlayışındaki ruhun madde ile birlikte ortaya çıktığı görüşü, İslam akidesindeki ruhun ölümsüzlüğü ilkesiyle çeliştiği için Müslüman filozoflar, ruh ve beden bütünlüğünü ifade eden nefs kavramını kullanmayı tercih etmişlerdir. Yaptıkları çalışmaları incelediğimiz zaman nefs ilmi çerçevesinde insan gelişimi, zihin ve fonksiyonu, ruh sağlı̆̆ı, motivasyon, kişilik ve davranışın ruhsal yönü gibi konuları ele aldıkları görülür.

İlk İslam filozofu olarak bilinen Kindî, nefs'i, Pisagor, Eflâtun ve Aristo'nun görüşlerini sentezleyerek 'Cisimde ve cisim vâsıtasıyla fonksiyonların gerçekleştiren cisimden bağımsız basit bir cevher' şeklinde tanımlamıştır. ${ }^{78}$ Nefs'i madde veya maddeyle ilişkili bir cisim üzerinden açıklamadığı dikkate alındığında Kindî’nin nefsi, yukarıda açıklamasını yaptığımız ruh kavramına yakın bir anlamda kullandığı anlaşılmaktadır. Buna göre nefs, beden içerisinde beden vasitasılla işlerlik kazanan bir özdür. Nefs ile ilgili risâlelerinde ${ }^{79}$, nefsin üç gücü, düşünme, arzu, öfke ve bunların doğru ve yerinde kullanılması ile gelişen adaletten bahsetmektedir. Yapılan bu dörtlü tasnif büyük ölçüde Aristo'nun yorumlarını içerir. Bunların yanında insanı dünya yaşamında üzüntüye düşüren sebeplerden korunma gibi etiğin pratik konularını işlemiş ${ }^{80}$ insana bilimsel bir yaklaşımdan çok felsefî nitelikte yaklaşmıştır. ${ }^{81}$

İslam düşünce tarihinde nefsi salt psikolojik anlamda kullanan ilk düşünür Muhâsibî (öl. 243/857) olmuştur. O, felsefi bir analizden çok tasavvuf psikoloj isi ve ahlak açısından nefs'e yaklaşmıştır. Er-Riâye li Hukûkillah ${ }^{82}$ adlı eserinde kişisel iç gözlemlerine dayanan davranış tahlilleri yaparak dinî bilinci sürekli canlı tutacak ilke ve yöntemler üzerinde durmuştur. Günümüz psikoloji tekniklerinden iç gözlemi kullanması oldukça dikkat çekicidir. Bu yöntem sayesinde nefsin yapısı ve özelliklerini tanımlamaya çalışan Muhâsîbî, bireyi ruhsal bozukluk

77 İlhan Kutluer, “ïlmü’n-Nefs”, Türkiye Diyanet Vakfi İslâm Ansiklopedisi (İstanbul: TDV Yayınları, 2000), 148-149.

78 Mahmut Kaya, "Kindî, Ya'kûb b. İshak", Türkiye Diyanet Vakfi İslâm Ansiklopedisi (Ankara: TDV Yayınlar1, 2002), 48-49.

79 Risâle fi'n-Nefs, Kelâmun fi'n-Nefs, Mâhiyetü'n-Nevm ve'r-Rü'yâ ve el-Hîle lidefil'-Ahzân nefs hakkındaki görüşlerini ihtiva eden başlıca risâleleridir.

80 Hökelekli, İslam Psikolojisi Yazıları, 19-20; Köse- Ayten, Din Psikolojisi, 87-88; Gül, İslam ve Psikoloji, 42-46. Nefse üzüntü veren başlıca iki unsur vardır. Bunlardan biri arzu edilmeyene maruz kalmak, diğeri arzu edilenden mahrum kalmaktır. Her iki durumda da insan kendisini varlığın gerçekliği ve hayatın geçiciliği bilgisi ile aydınlatarak üzüntüden kurtulabilir. Bunun yolu, kaçınılmazı kabullenmek, imkânsız olanı da arzulamamaktır.

81 Enver Uysal, "Kindî ve Fârâbî'de Akıl ve Nefs Kavramlarının Ahlâkî İçeriği”, Uludağ Üniversitesi ilahiyat Fakültesi Dergisi 13/2 (Haziran 2004), 150-153.

82 Hâris el-Muhâsibî - Abdülhakim Yüce, Kalp Hayatı (İstanbul: Işık Yayınları, 2011). 
diyebileceğimiz manevî tehlikelere karşı korumanın yollarını âyet, hadis ve bazı rivayetler bağlamında açıklamıştır. Âdâbu'n-Nüfûs adlı eserinde de benzer şekilde nefsin arınması ve eğitilmesinden bahseder..$^{83}$ Genel olarak bireyin dinî bilinç ile yaşayarak muhtemel ruhsal bozukluklara karşı kendini koruyabileceği kanaatindedir. Bir başka deyişle fonksiyonel haldeki dindarlık ruhsal sağlık durumuyla özdeşleştirilmiştir.

Kindî gibi filozof kimliğiyle öne çıkan Fârâbî (öl. 349/960) ise nefs hakkındaki görüşlerini büyük ölçüde Aristo'ya dayanmakla birlikte yeni Platoncu bir yorumla sentezleyerek İslâm akidesi ile uzlaştırmaya çalışır. Ona göre nefs, 'güç halindeki tabii cismin ilk yetkinliğidir (entelecheia)'. Bu tanıma uygun olarak güç, yetkinlik ve sûret olmak üzere nefse üç özellik atfetmektedir. Ancak nefsin sûret niteliğinin madde ile özdeşlemesine neden olacağının farkına varan Fârâbî, mahiyeti itibariyle nefsin bir cevher ama 'basit bir cevher' olduğunu ifade eder. ${ }^{84}$ Ona göre nefsin, ğâziyye (besleyici), nâmiyye (geliştirici), müvellide (üreme) kuvvelerine sâhip 'Bitkisel'; müdrike (idrâk edici), müteharrike (hareket ettirici) kuvvelerine sâhip 'Hayvânî' ve amelî-nazarî kuvvelere sahip 'İnsanî” olmak üzere üç boyutu vardır. Nefs ve psikolojik potansiyellerin bu taksimi Maslow'un ihtiyaçlar piramidini anımsatmaktadır. ${ }^{85}$ Ayrıca o, 'Faal Akll' kavramını İslam inancındaki vahiy meleği ile eşleştirerek dinî bir kavram olan vahyi, rüya ve ilham gibi süreçlere benzetmiştir. Vahyi, sezgisel bir haber alma olayı olarak tarif etmesi, dinî bir meseleyi bilimsel bakış açısıyla incelemenin ilk örnekleri arasında sayılabiliir. ${ }^{86}$

Yukarıda görüşlerini kısaca aktardığımız Kindî, Muhâsibî ve Fârâbî yanında Ebu Bekr Râzî (öl. 313/925) İbn Miskeveyh (öl. 421/1030) ve İbn Rüşd (öl. 594/1198) gibi filozof ve mutasavviflar, nefsi, ya ontolojik mâhiyetini dikkate alarak düşünceleri kavrama yetisi ya da etik düzlemde değerlendirerek bir ahlak teorisi geliştirme bağlamında ele almışlardır. ${ }^{87} \mathrm{Bu}$ teorilere dayanarak insan doğasını, sınırlarını, ruhsal anlamda zaaflarını tespit etmek ve ahlâkî açıdan iyileşmesi yolunda bir reçete sunmak her ne kadar mümkün gözükse de günümüz bilim anlayısıının yerini dolduracak nitelikte tıbbî inceleme ve tedavi yöntemleri açısından yetersiz kaldığı görülmektedir. Ebû Zeyd el-Belhî ve İbn Sînâ’nın çalışmaları tıbbî pratikler ile felsefenin ilkelerinin birleştirmeleri yönüyle bunlardan ayrılır.

Ebû Zeyd el-Belhî̀nin (öl. 322/934) nefs görüşü ve teorisi hakkında çok fazla bilgimiz yoktur. Ancak o Mesâlihu'l-Ebdân ve'l Enfüis ${ }^{88}$ adlı eseriyle klinik psikolojide akla

83 Nazife Varlı, "Erken Dönem İslâm Âlimlerinin Psikolojiye Katkıları: Akıl, Nefs, Ruh Kavramları", Hatay Mustafa Kemal Üniversitesi İlahiyat Fakültesi Dergisi 2/1 (2019), 77.

84 Gül, İslam ve Psikoloji, 49-50.

85 Köse - Ayten, Din Psikolojisi, 90-92.

86 Roger Arnaldez, "Farabi'nin Felsefe Sisteminde Nefs ve Alem”, çev. Hayrani Altintaş, Ankara Üniversitesi İlahiyat Fakültesi Dergisi 23/1 (Nisan 1979), 349-358.

87 Nefsin felsefi içeriği ve biyolojik yorumuna dair örnek için bk. Kusta b. Luka El-Yunani, "Ruh ve Nefs Arasındaki Fark Hakkında", çev. İbrahim Üçer, Marmara Üniversitesi İlahiyat Fakültesi Dergisi 36 (2009), 195-208.

88 Ebû Zeyd Ahmed El-Belhî, Mesâlihu'l-Ebdân ve'l Enfüs, çev. Muhammet Uysal (Samsun: Endülüs Kitap Yayınları, 2019). 
gelebilecek ilk düşünürlerdendir. Bu eserinde beslenme, uyku, cinsellik gibi günlük yaşam düzenini ilgilendiren beden sağlığı ile ilgili konular üzerinde durduğu gibi öfke, korku, kaygı ve hüzün gibi ruhsal bozukluklara ve bunların tedavi yöntemlerine de değinmiştir. Henüz 9.yy.'da psikoz ile nevrozu, bir başka deyişle zihinsel ve ruhsal bozuklukları birbirinden ayırmaya çalışması oldukça dikkat çekicidir. Ona göre duygusal durumumuzu düşüncemiz belirler. Yanlış düşünce endişe, öfke, üzüntü gibi duygusal bozukluklara neden olur. Kişi olumlu düşünce halinde gelecekteki muhtemel olumsuzluklara karşı̆ güç depolamalıdır. Eserinde sürekli olarak psikolojik rahatsızlıklar ile fiziksel bozuklukları kıyaslamış, bunların etkileşimlerinin nasıl psikosomatik hastalığa neden olduğunu ortaya çıkarmıştır. Yaptığı çalışmalarda psikolojinin ilkelerini izlemesi ve bunu yaparken İslam dünya görüşü içerisinde görüşlerini geliştirmesi konumuz açısından oldukça önemlidir.

İslam düşünürleri içerisinde psikolojiyle en çok ilgilenen ve bu alanda en çok eser veren isim İbn Sînâ'dır. Nefs hakkında büyük ölçüde Aristo ve Fârâbî etkisinde kalarak nefsi, 'Cinsin kendisiyle bilfiil varllk kazandığı ilk ilke' şeklinde tanımlamıştır. Nefsi ne madde ne de soyut bir cisim olarak değerlendirmiştir. Ona göre nefs, bedenin ruhla birleşmesinden doğan ve insanın kendisiyle insan olarak tanımlandığı bir ilkedir. Ruh ise Fârâbînnin görüşü aksine bedene ait bir fonksiyon değildir. Bunun dışında nefsle ilgili görüşleri büyük ölçüde Fârâbî'deki tasnife dayanır.

İbn Sînầnın çalışmamız açısından en önemli yönü tıbbî pratikleri felsefenin konuları ile buluşturmasıdır. Canlı varlıkların duygusal merkezi kabul ettiği 'vehim gücü'nü (el-kuvvetü'l-vehmiyye) psikoloji bilimine kazandırması, fizyolojik reaksiyonların ruh halleri ile ilişkisini ve psikolojik hallerdeki değişikliklerin önce duygusal sonra bedensel değişiklere neden olduğunu ortaya koyması ${ }^{89}$ İbn Sînâyı özel bir konuma taşımaktadır. Kimi araştırmalara göre ${ }^{90}$ psikanalizin bilinçaltındaki hatıra ve kompleks yaşantılara ulaşmada kullandığı 'ilişki test'lerini psikanalizin modern dönemdeki kurucusu Freud'dan çok daha önce ilk defa o kullanmıştır. ${ }^{91}$ Mu'cize, vahy, ilham ve keşf gibi dinî; nazar, büyü ve hipnoz gibi paranormal fenomenleri metafizik ile birlikte fiziği kullanarak açıklaması sadece İslam düşünürleri arasında değil aynı zamanda tüm düşünce tarihi içerisinde İbn Sînâ’yı kadim bilimle modern bilimi buluşturan şahıs olarak öne çıkarmaktadır.

Müslüman düşünürlerin insan psikolojisine dair ortaya koydukları fikirler, Kur'an ve hadisler özelinde yaptığımız değerlendirmeye benzer nedenlerle sadece İslamî bilgi birikimine dayalı oluşturulacak bir bilimsel disipline kaynaklık etme işlevselliğini tam anlamıla taşımamaktadır. Nitekim söz konusu görüşler daha çok felsefe ve etik sınırları içerisinde kalır. Ebû Zeyd el-Belhî ve İbn Sînâ'nın klinik psiko-

89 Kendisine gelen bir melankoli hastasının nabzını tutarak bazı mekân ve şahıs isimleri zikretmesi, bir isme geldiğinde nabzın hızlandığını görerek teşhiste bulunması bu konuda verilen örneklerden yalnizca biridir.

90 Fahrettin Kerim Gökay, "Türk ve İslam Ruh Hekimliği Tarihinde İbn-i Sina” 1. Uluslararası Türk-İslam Bilim ve Teknoloji Tarihi Kongresi, (İstanbul: İTÜ Mimarlık Fakültesi Baskı Atölyesi, 1981), 2/196.

91 Hökelekli, İslam Psikolojisi Yazıları, 21-22; Gül, İslam ve Psikoloji, 51-63. 
lojiyi kullanmaları ve bunu yaparken felsefi kavram ve kuramları psikolojiyle bağdaştırmaları ise günümüzde nasıl bir yöntem izleyebileceğimize ışık tutar niteliktedir. Bedri'nin öncülüğünde gelişen İslamî psikoloji el-Belhî ve İbn Sînâyı andırır biçimde sentezleyeci bir tutum üzerine şekillenmiştir.

\section{Günümüzde İslamî Psikoloji}

Bedri'nin 1975 yllındaki psikolojinin İslamîleştirilmesi vurgusundan bugüne geçen süreçte önemli adımlar atıldı. Bedri, yaptığı vurgu ve yayımladığı eserlerle yetinmeyerek 2017 yılında "Uluslararası İslamî Psikoloji Derneği/ The International Association of Islamic Psychology” (IAIP)'nin kurulmasına öncülük etti. Dernek bünyesinde insan psikolojisini anlamak, ruh sağllğı ve yaşam doyumuna katkı sağlamak misyonuyla çeşitli kurs ve sertifika programları oluşturuldu. Aynı zamanda bilimsel araştırmalarla alanı zenginleştirmek amacıyla İslamî Psikoloji Dergi'si (The Journal of Islamic Psychology) 2019 yılı ocak ayında yayım hayatına geçirildi. Kuruluşun (IAIP) felsefesine göre 'ìslamî psikoloji, benliğin ve ruhun doğasını ve ruhun İlahi olanla bağlantısını daha iyi anlamaya çalışan bütüncül bir yaklaşımdır. Kuran öğretileri, Peygamberlik öğretileri ve İslam geleneğinin ruh bilgisi üzerine temellendirilir. Modern psikolojiyi, geleneksel maneviyatı, metafiziği ve ontolojiyi kapsar.' Derneğin üyeleri arasında, Amber Haque, Rasjid Skinner, Abdallah Rothman, Hooman Keshavarzi, Yasien Mohamed gibi uzman klinik psikologları ve psikiyatristler yer almaktadir.

Șekil 1. tslamî Psikoloji șeması

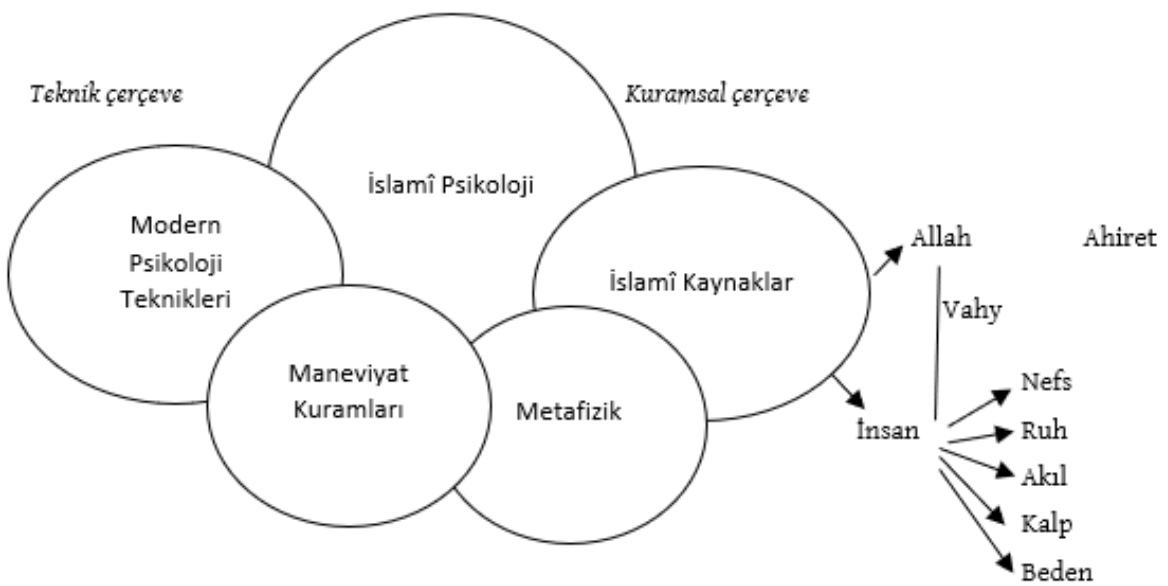

Şema 1'de görüldüğü üzere İslamî psikoloji, Kur'an, Peygamber ve kadim ruh bilimi birikimini kucaklayan, pratik uygulamalarla bunları modern psikolojiyle buluşturan bir bilim dalı olarak değerlendirilmektedir.

\section{Sonuç}

Modern psikolojiye tarihsel bakışımızda gördüğümüz üzere insan merkezli olma, deney ve denetime elverişli olanla bilimsel araştırmayı sınırlandırma gibi natüralist 
paradigmaya dayanan ilkeler hala devam etmektedir. Ancak insanın aşkın tabiatına karşı geliştirilen inkâr ya da daha yumuşak bir ifadeyle ihmal refleksi günümüze uzanan süreçte törpülenmiştir. Freud ve Jung'un bilinçaltı ya da dişı süreçlerce yönlendirilen edilgen insan anlayışı yerine Frankl'ın geliştirdiği tercih imkânı saklı insan anlayışı, bilinçdışı yoluyla Tanrı'ya bağlanma fikri ve dinin hayatı anlamlandırmada en bütüncül sistem olduğuna dair yorumu teknik olarak İslam dünya görüşüne uygun psikolojiye kapı aralamıştır.

Diğer yandan, İslâmî kaynakların ve Müslüman düşünürlerin ortaya koymuş oldukları psikoloji konusundaki teorilerin felsefe, ontoloji ve etiğin sınırlarında kalarak bilimsel etkinliğe kaynak olma yönünden işlevselliğini kaybettiğini görüyoruz. Geldiğimiz şu noktada ne sadece modern psikolojiye ne de sadece İslamî kaynaklara dayanarak bilimsel disiplinin gerekliliğini taşıyan bir İslamî psikolojinin oluşturulabileceğini söyleyebiliriz. Ya da daha ılımlı bir ifadeyle söylersek bu tür denemeler, tümüyle sonuçsuz olmasa da yetersiz kalacaktır. Zira modern psikoloji arka planını oluşturan 'aydınlanma' fikirlerinden, insan ve dünya görüşünden tamamen kopabilmiş değildir. Tanrı'nın varlı̆̆ı ve etkisini artık göz ardı etmiyorsa bile Tanrı-insan arasındaki ilişkiyi hala ıskalıyor. Öte yandan İslamî kaynaklardaki bilgiler bütüncül bir ruh anlayışı ortaya koymakla birlikte fazla kavramsal ve teorik düzeyde kalıyor. Bu nedenle İslamî psikolojinin oluşturulması adına IAIP'nin perspektifine uygun olarak hem kavramsal doygunluğu hem pratik etkiyi hem de evrensele hitap işlevselliği dikkate alınarak bir sentez yapılması gerekir. Allah, âlem ve insan anlayışı İslamî kaynaklardan beslenirken kullanılan kavram ve teknikler modern psikolojiden alınmalıdır.

Bu bağlamda Budist gelenekte doğan ancak bilimsel zemine taşınarak evrensel bir karakter kazandırılan bilinçli farkındalık, kabul ve bağlılık gibi farklı meditasyon tekniklerinin günümüzdeki uygulamaları da dikkate alınabilir. Benzer şekilde İslam din ve maneviyatında köklerini bulan, insanı daha doğru ve sağlıklı yaşama götüren İslamî kaynaklardaki bilgi ve tecrübeler, bilimsel zemine aktarılmalı ve insanlığın istifadesine sunulmalıdır. İslamî psikolojinin etkin kullanılması adına yaşam memnuniyetini artıran, zorlu yaşam tecrübeleriyle başa çıkmada yardımcı olan; kısacası pratik sonuçları besleyen bilgi ve tecrübelere özellikle dikkat çekmek gerekir. Böylece kuram ile uygulamanın bir araya getirilebileceği uygun zemin oluşturulabilir. Ayrıca kabul ve bağlllık terapisi gibi kader ve teslimiyet yahut bilinçli farkındalık gibi niyet ve ihlas terapileri geliştirilebilir. Böylece zengin ve bütüncül kuramsal çerçeveye sahip İslamî gelenek hem İslam dünya görüşüne sahip bireyleri daha iyi anlayıp, ifade edecek hem de modern insanı çağın bunalımlarından çıkaracak evrensel bir sistem oluşturacaktır. Bu doğrultuda el-Hîle li Defi'l-Ahzân, Risâle fì Defi i Gammi'lMevt gibi klasik felsefî eserlerin güncel psikoloji teorileriyle karşlaştırmalı olarak ele alınması, insanı estetik nazarıyla betimleyen Yunus ve Mevlânâ gibi şahsiyetlerin dîvânlarının psikolojik tahlili ve peygamber, sahâbî, âlim zevâtın psiko-biyografik değerlendirmelerine başvurulması önerilir. Akabinde elde edilen kuramsal yapı, pratik uygulamalarda istihdam edilecek işlevselliğe kavuşturulacaktır. 


\section{Kaynakça}

Ağılkaya, Zuhal ş. "Müslüman Psikologlar Kertenkele Deliğinden Çıktı Mı? İslami Psikoloji Alanındaki Gelişmeler”. Journal of Turkish Studies 14/2 (Ocak 2019), 15-47.

Altun, Veysel K. “İslam Düşüncesini Yeniden İnşa Çabası: Bilginin İslamileştirilmesi”. Birey ve Toplum Sosyal Bilimler Dergisi 4/2 (Temmuz 2015), 163-192. https://doi.org/10.20493/bt.01458

Amber Haque. “İslamî Bir Perspektiften Psikoloji ve Din Arasındaki İlişki ve Bütünleşme”. çev. Mustafa Koç. Uludağ Üniversitesi İlahiyat Fakültesi Dergisi 20/1 (2011), 227-258.

Armaner, Neda. Din Psikolojisine Giriş. Ankara: Ayyıldız Matbaası Yayınları, 980.

Arnaldez, Roger. “Farabi'nin Felsefe Sisteminde Nefs ve Alem”. çev. Hayrani Altintaş. Ankara Üniversitesi İlahiyat Fakültesi Dergisi 23/1 (Nisan 1979), 349-358. https://doi.org/10.1501/Ilhfak_0000000571

Aydın, Hayati. Kur'an'da İnsan Psikolojisi (Olumsuz Ruh Halleri ve Davranışları Yönüyle). Ankara: Fecr Yayınları, 7. Basım, 2016.

Aynî, Mehmet Ali. "Nefs Kelimesinin Manaları". Darülfunun İlahiyat Fakültesi Mecmuası 1/14 (1930), 45-52.

Ayten, Ali. “Arap Ülkelerinde İslami Psikoloji ve Din Psikolojisi Çalışmaları”. Çukurova Üniversitesi İlahiyat Fakültesi Dergisi 12/2 (2012), 51-98.

Ayten, Ali. Psikoloji ve Din: Psikologların Din ve Tanrı Görüşleri. İstanbul: İz Yayıncılık, 2. Basım, 2010.

Badri, Malik B. "Psychological Reflections on Ismail Al-Faruqi's Life and Contributions”. American Journal of Islamic Social Sciences 31/2 (2014b), 145-152.

Badri, Malik Babikir. Müslüman Psikologların İkilemi. çev. Aynur Tutkun. İstanbul: Safa Yayın Dağıtım, 2016.

Bahadır, Abdülkerim. "Psikoterapi'de Yeni Bir Yaklaşım: Logoterapi ve Viktor Frankl”. Uludă̆ Üniversitesi İlahiyat Fakültesi Dergisi 9/9 (Ocak 2000), 469-485.

Bakar, Osman. İslam Bilim Tarihi ve Felsefesi. çev. Işık Yanar. İstanbul: İnsan Yayınları, 4. Basım, 2016.

Baymur, Feriha B. Genel Psikoloji. İstanbul: İnkılâp Yayınları, 27. Basım, 2020.

Belzen, Jacob A. - Hood, Ralph W. "Methodological Issues in the Psychology of Religion: Toward Another Paradgim?" The Journal of Psychology 140/1 (2006), 5-28.

Blachére, Regis. “'Nefs’ Kelimesinin Kur’an'da Kullanışı Hakkında Bazı Notlar”. çev. Sadık Kılıç. Atatürk Üniversitesi İlahiyat Fakültesi Dergisi 5 (Haziran 1982), 189-196.

Çalık, Fatma. “Bir Semantik Analiz Denemesi: Kur'ân'da 'Kalp' Kavramı”. Uludağ Üniversitesi İlahiyat Fakültesi Dergisi 20/2 (Haziran 2011), 167-190.

Davutoğlu, Ahmet. “Medeniyetlerin Ben-idrâki”. Divan: Disiplinlerarası Çalışmalar Dergisi 3 (Aralik 1997), 1-53.

Doğrul, Ömer Rıza. “ílmü’n-nefs ve Din”. çev. Hüseyin İbrahim Yeğin. Abant İzzet Baysal Üniversitesi İlahiyat Fakültesi Dergisi 3/5 (Haziran 2015), 254-265.

Düzgüner, Sevde. "Dini Psikoloji ve İslam Psikolojisi Bağlamında Din Psikolojisini Yeniden Düşünmek". İslâmî İlimler Dergisi 12/3 (2017), 133-163.

Ebû Zeyd Ahmed El- Belhî. Mesâlihu'l-Ebdân ve'l Enfüs. çev. Muhammet Uysal. Samsun: Endülüs Kitap Yayınları, 2019.

El-Yunani, Kusta b. Luka. "Ruh ve Nefs Arasındaki Fark Hakkında". çev. İbrahim Üçer. Marmara Üniversitesi İlahiyat Fakültesi Dergisi 36 (2009), 195-208. https://doi.org/10.15370/muifd.61768

Faruki, İsmail R. Bilginin İslamileştirilmesi: Genel İlkeler ve Çalışma Planı. çev. Fehmi Koru. İstanbul: Risale Yayınları, 1985. 
Forsyth, James. Psikolojik Din Kuramları. ed. Mustafa Ulu. Kayseri: Kimlik Yayınları, 2017.

Frankl, Victor. Psikoterapi ve Din: Bilinçdışındaki Tanrı. çev. Zeynep Taşkın. İstanbul: Say Yayınlar1, 1. Basım, 2014.

Frankl, Victor E. Anlam İstenci: Logoterapinin Temelleri ve Logoterapi Uygulamaları. çev. Mustafa Yalçınkaya. İstanbul: Öteki Yayınevi, 2018.

Frankl, Victor Emile. Der unbewußte Gott: Psychotherapie und Religion. München: dtv Verlagsgesellschaft mbH, 14. Basım, 2017.

Frankl, Viktor E - Atayman, Veysel. Hayatın Anlamı ve Psikoterapi. Istanbul: Say Yayınları, 3. Basim, 2019.

Freud, Sigmund. Din. çev. Nursel Yıldız. İstanbul: KafeKültür Yayıncılık, 1. Basım, 2015.

Freud, Sigmund. Moses and Monotheism. çev. Katherine Jones. London: Hogarth Press, 1939.

Freud, Sigmund. Totem and Taboo. London: Penguin Freud Library, 1990.

Gökay, Fahrettin Kerim. “Türk ve İslam Ruh Hekimliği Tarihinde İbn-i Sina”. 2/196. İstanbul: İTÜ Mimarlık Fakültesi Baskı Atölyesi, 1981.

Gül, Esan. İslam ve Psikoloji. İstanbul: Çıra Yayınları, 2015.

Gürses, İbrahim. “Jung'cu Arketip Teorisi Bağlamında Tasavvufî Öykülerin Değerlendirilmesi: Sîmurg Örneği”. Uludağ Üniversitesi İlahiyat Fakültesi Dergisi 16/1 (Ocak 2007), 77-96.

Hall, Calvin S. Freudyen Psikolojiye Giriş. çev. Ersan Devrim. İstanbul: Kaknüs Yayınları, 3. Basım, 2016.

Haque, Amber vd. "Integrating Islamic Traditions in Modern Psychology: Research Trends in Last Ten Years". Journal of Muslim Mental Health 10/1 (Temmuz 2016), 75-100. https://doi.org/10.3998/jmmh.10381607.0010.107

Hâris el-Muhâsibî - Yüce, Abdülhakim. Kalp Hayatı. İstanbul: Işık Yayınları, 2011.

Hökelekli, Hayati. İslam Psikolojisi Yazıları. İstanbul: Değerler Eğitim Merkezi Yayınları, 3. Basım, 2017.

Hökelekli, Hayati. Psikolojiye Giriş. Bursa: Emin Yayınları, 5. Basım, 2015.

Hökelekli, Hayati. “Türkiye'de Din, Dindarlık ve Din Psikolojisi Araştırmaları: Psikolojide Yerelellik ve Evrensellik TartışmalarıI Bağlamında Bir Değerlendirme”. Dokuz Eylül Üniversitesi İlahiyat Fakültesi Dergisi Din Psikolojisi Özel Sayısı (Nisan 2016), 311-333. https://doi.org/10.21054/deuifd.284626

İbnü'l-Manzur. Lisânü'l-Arab. 16 Cilt. Beyrut, 1994.

İslamoğlu, A. Hamdi - Alnıaçı, Ümit. Sosyal Bilimlerde Araştırma Yöntemleri. İstanbul: Beta Yayınları, 6. Basım, 2019.

Kasapoğlu, Abdurrahman. Carl Gustav Jung'un Kehf Suresi Tefsiri. Malatya: Huzur Matbaa, 1. Basim, 2006.

Kaya, Mahmut. "Kindî, Ya'kûb b. İshak". Türkiye Diyanet Vakfi İslâm Ansiklopedisi. 26/41-58. Ankara: TDV Yayınları, 2002.

Kızılgeçit, Muhammed. “İzmirli İsmail Hakkı'nın ‘İlmü’n-Nefs’inde Modern Psikoloji Tarihi”. Dinbilimleri Akademik Araştırma Dergisi 13/1 (Şubat 2013), 157-173.

Korkman, Hamdi. "Pozitif Bir Bilim Olarak Psikoloji”. Afyon Kocatepe Üniversitesi Sosyal Bilimler Dergisi 21/1 (Mart 2019), 345-357. https://doi.org/10.32709/akusosbil.426592

Köse, Ali - Ayten, Ali. Din Psikolojisi. İstanbul: Timaş Yayınları, 8. Basım, 2018.

Köse, Ali - Ayten, Ali. “Sigmund Freud”. Doğu'dan Batı'ya Düşüncenin Serüveni. 3/603-613. İstanbul: İnsan Yayınları, 2017.

Kutluer, İlhan. “ilmü’n-Nefs”. Türkiye Diyanet Vakfi İslâm Ansiklopedisi. 22/148-151. İstanbul: TDV Yayınları, 2000. 
Küçükalp, Kasım - Cevizci, Ahmet. Batı Düşüncesi: Felsefi Temeller. Ankara: İSAM Yayınları, 5. Basım, 2018.

La Mettrie, Julien Offray de. L'Homme Machine. Leiden: Elie Luzac Fils, 1748.

Mehmetoğlu, Ali Ulvi. “Jung'un Tanrı Anlayışı”. Toplum Bilimleri Dergisi 7/14 (2013), 10-15.

Mümtaz Ali, Mohammad. "İslam Düşüncesi ve Medeniyetinin Yeniden Yapılanması: Bilginin İslamileştirilmesi Akımının Analizi”. çev. Ömer Aydın. Journal of Istanbul University Faculty of Theology 5 (Nisan 2012).

Müslim. “Kitâbü'l-Kader”. Sahîh. Kâhire: Dârü's-Selâm, 1956.

Necâtî, Osman. “Hadis ve Psikoloji”. Ankara: Fecr Yayınları, 3. Basım, 2016.

Necâtî, Osman. Kur'an ve Psikoloji. Ankara: Fecr Yayınları, 4. Basım, 2017.

Özbay, Ekrem. İslam Psikolojisi ve İslam. Istanbul: IQ Kültür Sanat Yayıncllı, 2016.

Rasjid Skinner. “İslam Psikolojisinde Gelenekler, Paradigmalar ve Temel Kavramlar”. çev. Nevzat Gencer. Hitit Üniversitesi İlahiyat Fakültesi Dergisi 36 (2019), 671-683.

Robinson, Daniel N. Psikolojinin Felsefi Tarihi (An Intellectual History of Psychology). çev. Deniz Uludağ. Ankara: Doğu Batı Yayınları, 2020.

Rothman, Abdallah - Coyle, Adrian. "Conceptualizing an Islamic psychotherapy: A grounded theory study". Spirituality in Clinical Practice 7/3 (2020), 197-213. https://doi.org/10.1037/scp0000219

Sayar, Kemal - Dinç, Mehmet. Psikolojiye Giriş. İstanbul: Değerler Eğitim Merkezi Yayınları, 5. Basım, 2014.

Schultz, Duane P - Schultz, Sydney Ellen. Modern Psikoloji Tarihi. çev. Yasemin Aslay. İstanbul, 8. Basim, 2020.

Şentürk, Habil. “Freud'un Psikoloji ve Din Anlayışına Eleştirel Bir Yaklaşım”. Dini Araştırmalar 7/19 (Haziran 2004), 221-229.

Şentürk, Habil. İbadet Psikolojisi: Hz. Peygamber Örneği. İstanbul: İz Yayıncılık, 2008.

Uludağ, Süleyman. "Lübb". Türkiye Diyanet Vakfi İslâm Ansiklopedisi. 27/241. İstanbul: TDV Yayınları, 2003.

Uysal, Enver. Ahlaki Varlkk Olarak İnsan. Bursa: Emin Yayınları, 2. Basım, 2018.

Uysal, Enver. “Kindî ve Fârâbî’de Akıl ve Nefs Kavramlarının Ahlâkî İçeriği”. Uludağ Üniversitesi İlahiyat Fakültesi Dergisi 13/2 (Haziran 2004), 141-156.

https://dergipark.org.tr/tr/pub/uluifd/163007

Uysal, Saliha. Gelenek İle Gelecek Arasında İslamî Psikoloji. İstanbul: Çamlıca Yayınları, 1.Basım, 2021.

Varlı, Nazife. "Erken Dönem İslâm Âlimlerinin Psikolojiye Katkıları: Akıl, Nefs, Ruh Kavramlar1". Hatay Mustafa Kemal Üniversitesi İlahiyat Fakültesi Dergisi 2/1 (2019), 67-89.

Zeyn, Semih el-Âtıf. Ma'rifetü'n-Nefsi'l-Insâniyye. Beyrut: Dârü'l-Küttâbi'l-Lübnânî, 1991. 